\title{
‘SUCH A WHITE THING TO DO’: A DISCOURSE ANALYSIS OF CAMH'S COPING WITH COVID-19 CAMPAIGN
}

by

McKaila Sullivan, BSW, University of Victoria, 2019

\author{
An MRP \\ presented to Ryerson University \\ in partial fulfillment of the \\ requirements for the degree of \\ Master of Social Work \\ in the Program of \\ Social Work
}

Toronto, Ontario, Canada, 2020

(C) McKaila Sullivan 2020 


\section{AUTHOR'S DECLARATION FOR ELECTRONIC SUBMISSION OF A MRP}

I hereby declare that I am the sole author of this MRP. This is a true copy of the MRP, including any required final revisions.

I authorize Ryerson University to lend this MRP to other institutions or individuals for the purpose of scholarly research

I further authorize Ryerson University to reproduce this MRP by photocopying or by other means, in total or in part, at the request of other institutions or individuals for the purpose of scholarly research.

I understand that my MRP may be made electronically available to the public. 


\begin{abstract}
'Such a white thing to do': A discourse analysis of CAMH's Coping with COVID-19 Campaign

Master of Social Work, 2020

McKaila Sullivan

Program of Social Work, Ryerson University

This major research paper is a modified critical discourse analysis of lived experience testimonials from the Centre for Addiction and Mental Health (CAMH)'s Coping with COVID19 campaign. Social work practitioners and researchers must consider the inherent violence in the complex manifestations of sanism and racism (re)produced through discourse and their inextricable confluence with institutions, colonial legacies and realities which operate at this juncture in support of white supremacy. The identified discourses reproduce the ideal neoliberal subject and operate as technologies which maintain the colonial project and white supremacy. If we stake any claim to anti-racist praxis at this juncture, it is necessary to radically disclose our complicity within this colonial project, acknowledge our confluent realities and interrogate any claim to anti-racism. If we fail to interrogate these discourses constructing madness, we not only permit the violent trajectory of sanism but operationalize the deeply entrenched (re)production of violent white supremacy.

key words: critical discourse analysis, sanism, racism, white supremacy, psychocentrism
\end{abstract}




\section{ACKNOWLEDGEMENTS}

To Jess- who will now call out "that's sanism!" because of our lengthy conversations and an unsolicited education in critical theory, who not only supports every bit of our journey with unwavering love but reminds me of the power of knowledge exchange to change and disrupt discourse. Thank you for believing in me, especially when I didn't.

Thank you to Jennifer Poole for the inspiration, guidance and unwavering support. I think your presence transcends the role of supervisor and I am completely grateful for all you have done for me.

To all the instructors who expanded my mind and fostered a supportive, nurturing environment when the walls of academia typically close in- thank you. To all my cohort mates and every person who I've crossed paths with on this year long, intense, unprecedented journey- thank you, too, for reminding me why we're social workers.

And finally, to my darling little Benjamin, the only reason I breathe and run and dance- your giant, tiny hugs keep me going. This is all for you, kid. You'll move mountains.

Words are power. 


\section{DEDICATION}

For Benjamin 


\section{TABLE OF CONTENTS}

$\begin{array}{ll}\text { Introduction } & 1\end{array}$

$\begin{array}{ll}\text { Positionality } & 2\end{array}$

Chapter 1. LITERATURE REVIEW

Mental Health During COVID-19: A Necessary Context 5

$\begin{array}{ll}\text { Mass Media and Psychocentrism } & 9\end{array}$

$\begin{array}{ll}\text { Chapter 2. THEORETICAL FRAMEWORK } & 16\end{array}$

$\begin{array}{ll}\text { Why not Mad Studies? } & 16\end{array}$

$\begin{array}{ll}\text { Antipsychiatry } & 17\end{array}$

$\begin{array}{ll}\text { Postcolonialism } & 19\end{array}$

$\begin{array}{ll}\text { Confluence } & 20\end{array}$

$\begin{array}{ll}\text { Chapter 3. METHODOLOGY } & 21\end{array}$

Critical Discourse Analysis (CDA): language as social practice 21

$\begin{array}{ll}\text { Why CDA? } & 23\end{array}$

$\begin{array}{ll}\text { Data Collection } & 23\end{array}$

$\begin{array}{ll}\text { Data Analysis } & 25\end{array}$

$\begin{array}{lr}\text { Chapter 4. FINDINGS } & 29\end{array}$

$\begin{array}{ll}\text { The 'good, mad subject' } & 29\end{array}$

Discourse 1: Responsibilization: individualism and necessary service to others 32

Discourse 2: Successful recovery is a return to work: neoliberal productivity

$\begin{array}{ll}\text { and enterprise } & 34\end{array}$

Discourse 3: Mental health is health: sane-healthism 36

Discourse 4: Madness as deviance, violence and dangerousness: 
The continued confluence of mental health and carceral systems 38

Discourse 5: We are all in this together: individualized collectivism 41

$\begin{array}{ll}\text { Chapter 5. DISCUSSION } & 46\end{array}$

Context: History understood in its contemporary manifest 47

Discourse of dangerousness and violence as colonial technology 52

$\begin{array}{ll}\text { Coopting collectivism } & 54\end{array}$

Implications and recommendations $\quad 56$

$\begin{array}{ll}\text { Resisting positivism } & 57\end{array}$

$\begin{array}{ll}\text { Chapter 6. CONCLUSION } & 59\end{array}$

$\begin{array}{ll}\text { REFERENCES } & 63\end{array}$ 


\section{INTRODUCTION}

\section{Words are power}

2020. A year we will all remember for the rest of our lives. The radical overhaul of our way of life coincided with intense, seemingly endless changes in my personal life. I am reminded of Ameil Joseph's (2015) description of confluence as a river system, in which reality flows, constantly combining and reimagining, within the confines of a temporal space which is bound yet simultaneously infinite. I refer to confluence throughout this research as a defining concept informing my theoretical orientation, and its presence at this juncture in my life is uncanny. Perhaps its use is more reflective of my own state of being than can be explained, in which the constant movement of our realities is so aptly compared to a river. What Joseph didn't disclose, however, is that in reality, this river moves lightning fast.

Fuchs (2020) writes "the coronavirus crisis is a rupture and existential crisis of society that poses both potentials for the development of socialism and solidarity on the one side and slavery and fascist dictatorship on the other side" (p.380). This current juncture is rife with disruption, stress, fear, violence and continued injustice. Alongside this overhaul of our complacency has come a reckoning and hopeful revolution addressing the existent, deep seated racial injustice and violent white supremacy which permeates our social realities. We've been calling out systemic racism, murder and violence for some time and there has been resistance as long as its existed, but now this reality is dominating mainstream rhetoric, involving increasing numbers of white bodies encouraging movement and protest across Toronto and the globe. The toppling of statues commemorating architects of genocide and the "defacing" of an Egerton Ryerson statue have been heartful moments where I'm hopeful for the future and a shift in discourse, yet I can't help but consider the possibility this new wave of mainstream resistance 
and claims to white "allyship" may fade. Despite the increased use of terms in mainstream media referencing anti-racism and Black Lives Matter in dominant discourse, there remains little examination of colonialism or white supremacy as insidious realities dominating our institutions and permeating our bodies.

Reisigl and Wodak (in Fairclough, 2010) write "racist opinions and beliefs are produced and reproduced by means of discourse...through discourse, discriminatory, exclusionary practices are prepared, promulgated and legitimized (p.46). My MRP research is interested in furthering critical inquiry through discourse analysis as a means to examine and extrapolate the discursive technologies which construct madness, simultaneously supporting the colonial project and white supremacy. I am also interested in promoting Joseph's (2015) theory of confluence as a highly useful concept in social work research, its use in developing a theoretical framework when examining discourses and encouraging social work researchers to wholly indict themselves in their complicity to the systems we seek to resist (Joseph, 2015). I intend to highlight how contemporary discourses constructing madness in this digital media campaign operate in confluence to reproduce the neoliberal mad subject according to a eugenic rationale, which in turn function as technologies of colonialism in support of white supremacy (Joseph, 2019). The application of this examination will direct our understanding to this campaign as a discursive mechanism insidiously (re)producing discourses which not only normalize identified oppressions of sanism and racism but exist in confluence to facilitate technologies which support the continued project of white supremacy.

\section{Positionality and a note on sanism}

My chosen use of the term Mad throughout this work is reflective of my ethical position as simply refusing all violence and white supremacy. As Joseph (2015) describes: 
The term mad has been used 'as a generic name for the whole range of people thought to be in some way, more or less, abnormal in ideas or behaviour' (Porter 1987, 6). Mad is used when referring to the experiences and plight of peoples deemed mad throughout history. The concept of mental illness, psychiatric disturbance, or insanity often applies to more recent societal constructs or differences in behaviour or ideas (p.1022).

To my fellow social workers who are all implicated, I see and hear you. We are all a product of this infinitely complex machine and I too am implicated, indictable and human. We know the following is true; as Poole et al. (2012) described nearly a decade ago, sanism is still in our social work classrooms, living, breathing and permeating our bodies. To every coconspirator and claimant to anti-racist and anti-sanist praxis, I hear you and I see you, but I also ask that we critically see ourselves, stop writing reflexivity on paper and start truly embodying it through radical admission of complicity. We can make claims to anti-sanism in 2020, but the truth is no one is absolved from the system and these perspectives, inclinations and biases run bone deep. In so many words, my fellow social workers, you've told me and I acknowledge its embodiment myself.

I am all too familiar with the common requirement of listing off our positionalities as social work students and I do think it is important to acknowledge my spaces of privilege and privilege-passing as a means of socially locating. I am white, I am cisgendered, I pass as het and pass as able-bodied. But I am also a mother. These are aspects of who I am which I will share as it clearly informs my analysis, but I also call to task the politics of disclosure in revealing anything further. There is safety in what I disclosed. To you, dear reader, I don't necessarily know you, let alone trust you. My experience dictates that my words may be used against me, may be co-opted to undermine me and the risk inherent with disclosing what is perceived as wrong with me can and will likely follow me through my work and activism. For that reason, I take a political stance of ambiguity in this paper for the sake of my life, my children and my 
work in the spaces of my being that I hold most dear. I will not compromise my voice to the power of regulatory colleges and sanist praxis which exist and are designed to silence. For that reason, you may draw your own conclusions from the position I speak and glean tacit information from my contempt for a system which disables me. Those of you who know me, you know exactly where I'm coming from.

Strategic circumvention requires a great deal of ambiguity, although I wish a paper, arguably so frivolous, did not exist with the potential to be weaponized and wielded for my own disenfranchisement. Another example of words as power and I experience this within the safety of a white body. I also acknowledge the immense, complex privilege inherent in claiming ambiguity in this moment as it is such a white thing to do. The power of regulatory colleges (Chapman, Azvedo, Ballen \& Poole, 2016) is alluded to throughout this data, in which one individual lost their teaching job simply due to a "depression diagnosis" (Siolkowsky, Case 6, 2020, para. 1). This reality is actively normalized if not lauded as practice. I question the reality in which I and many others feel unsafe to disclose our true selves, in which we are only seeking revolution, yet our true selves are weaponized against us to keep us from disrupting the status quo. The entirety of my being and experience absolutely informs this work and writing, it is impossible to deny. So, from that, I encourage you to draw your own conclusions about the lens from which I speak. 


\section{CHAPTER 1. LITERATURE REVIEW}

\section{Mental Health During COVID-19: A Necessary Context}

It hit like a tonne of bricks; first we're here, moving, gliding, performing- then we aren't. The world shut down in a matter of days and in the midst of a global pandemic, "mental health" and the survival of our society came to the forefront of trendy social rhetoric and the COVID-19 response. "Wide-ranging public health measures" such as social distancing, quarantine and isolation have been implemented across the globe in an attempt to curb the spread of a highly contagious infection (Fuchs, 2020 p.376) and causing a "space-time" disruption (p.396). This in turn has impacted what Fuchs (2020) terms "everyday communication and sociality", radically reorganizing it "at a distance" and substituting virtually "mediated social relations" (p.377) in place of face to face contact.

This shift into our contemporary existence accompanied a surge in academic literature citing the undoubted, "widespread emotional distress" and "increased risk for psychiatric illness" associated with COVID-19 (Pfefferbaum \& North, 2020, p.1). The "mental health" of healthcare workers (Greenberg, Docherty, Gnanapragasam \& Wessely, 2020 ) and "patients with mental health disorders" (Yao, Chen \& Xu, 2020; Liu, Yang, Zhang, Xiang, Liu, Z., Hu, \& Zhang, 2020), as well as the relationship between COVID-19 and community mental health (Rajkumar, 2020; Vigo, Patten, Pajer, Krausz, Taylor, Rush \& Yatham, 2020) have been the subject of many academic publications in recent months, dominated by The Lancet Psychiatry and similar medical journals. A brief review of the available literature related to mental health during COVID-19 reveals its framing as both an economic and public health crisis, predominantly presented through the biomedical lens of psychiatry. The dominance of psychiatric journals governing the available literature is reflective of knowledge gatekeeping, and although we are 
still in the first few months of this pandemic, this initial presentation of literature enlightens us to who is being funded, what research is being conducted and what ideology is being pushed in the rhetoric of academic of publications. Now, more than ever, media campaigns and initiatives attempting to normalize mental health diagnoses and "reduce stigma" (CAMH, 2020) are gaining traction in an increasingly digital environment. The timing of this analysis is crucial to note, as the use of new media as the dominant form of information sharing and social interaction due to physical distancing policies and isolation during COVID-19 (Wiederhold, 2020) is unprecedented.

Fuchs (2020) indicates "communication technologies play a decisive role in organising everyday life from the locale of the home in the coronavirus crisis" (p.382). This unprecedented increase in mediating communication technology and social media exchange should be analyzed for its potential to operate as a powerful, rapidly infiltrative discursive mechanism (Ohlsson, 2018) or site of discursive practice, described by Fairclough (in Bacchi \& Bonham, 2014) as "the production, distribution and consumption of texts" (p.174). For example, micro blogging is now commonly considered a primary news source, shifting from traditional news media to platforms such as Twitter (Nguyen, 2011). Twitter has gained social legitimacy as a reliable source of knowledge and is operationalized as a powerful platform to (re)produce and disrupt dominant discourses and political narratives (Nguyen, 2011; Graham \& Smith, 2016). This new reality of knowledge exchange combined with the recent push of marketing campaigns such as Bell Media's (2010) Let's Talk and the Centre for Addiction and Mental Health (CAMH)'s (2018) Mental Health is Health campaign through social media require critical analysis, considering their infiltrative potential and the topical relevance of mental health during COVID-19. Both the 'Let's Talk' and 'Mental Health is Health' campaigns each claim to "spread mental health 
awareness" through social media (Peters, 2018, p.395) to reduce stigma as a social barrier to diagnosis and treatment (CAMH, n.d.), allowing individuals to "overcome mental health issues" (Peters, 2017, p. 404) and achieve social change (Centre for Addiction and Mental Health, 2018). CAMH is self-described through their webpage as "Canada's largest mental health teaching hospital", setting "the standards for care, research, education and leading social change" (n.d.). CAMH (2018) claims Mental Health is Health is their most "ambitious public awareness campaign in years" with a message that "the mental health of all Canadians must be taken as seriously, and treated as urgently, as physical health" (para. 5).

According to CAMH president and CEO Dr. Catherine Zahn, who states "we must not stand silent when the human, the civil and the health care rights of people with mental illness are not recognized and respected" (CAMH, 2018, para. 4), universally accessible psychiatric treatment is the primary issue and framed as a "fight for justice" (para. 8), in which "all Canadians should have access to publicly funded, life-saving treatments like cognitive behavioral therapy and magnetic brain stimulation" (para. 9). According to Zahn, "advocacy is deeply embedded in the CAMH mission" (CAMH, 2018, para. 3) and this campaign invites users to "join the movement" and "become a change agent" through their engagement with social media, in which "changing attitudes, behaviours and culture is the only way to create a world where Mental Health is Health" (CAMH, 2020).

Referring to Mental Health is Health, CAMH (2020) claims "mental health awareness campaigns like this and Bell Let's Talk have the potential to convince people to stop suffering in silence and seek help, which is fantastic" (para. 3). The dominant discourses and constructions of madness (re)produced within these campaigns should be subject to analyses, considering their level of influence and relationship to the subjectification of the masses (Jacob \& Skinner, 2015), 
while touted as progressive, social solutions to a rapidly increasing social problem. The transformative potential of critical interrogation is in its ability to facilitate space for the reconstruction or reconceptualization of "socially shared knowledge" (Ohlsson, 2018, p.312) and to identify the ways in which many dominant perspectives in mass media are in fact, problematic.

According to Goffman in Ahmedani (2011), stigma is "an attribute that is deeply discrediting" (p.2) consisting of "stereotypes or negative views attributed to a person or groups of people when their characteristics or behaviors are viewed as different from or inferior to societal norms" (Dudley in Ahmedani, 2011, p.2). To focus on anti-stigma and awareness campaigns as a social solution to stigma within the context of mental health absolves any attention to sanism or structural violence. Sanism is as an active, complex form of operationalized violence and oppression toward folx who deviate from prescriptive sane norms (Leblanc \& Kinsella, 2016; Perlin, 2013; Poole et al., 2012). Sanism is the deep, institutionalized violence which permits human rights abuses and the "systematic subjugation of people who have received "mental health" diagnoses or treatment" (Poole et al. 2012, p. 20). Sanism relies on discourses which co-construct mad bodies as inherently pathological, deviant, diseased (Leblanc \& Kinsella, 2016) or "brainsick" and "violent” (Menzies, LeFrançois \& Reaume, 2013, p. 192) to rationalize "forms of violence on bodies of difference deemed worthy of harm or exclusion" (Joseph, 2015, p.1037). The concept of stigma describes harm as entirely attitudinal in its origin, the result of individual perspectives and equally remedied through the changed perspective of the individual- while deflecting any attention from the complex systems and institutions which, through an historic trajectory steeped in colonialism (Joseph, 2015), continually co-construct subjects of deviance and normality according to neoliberal discourses (Oute, Juniche, Nielsen \& 
Anders, 2015) to operationalize violence on prescribed bodies. The absence of any attention to sanism throughout much 'mental health' literature may be partially reflective of its lack of mainstream use as language, however we must necessarily avoid conflating stigma with sanism as interchangeable concepts and consider the absence of articulated sanism a problematic omission, in itself reflective of its underlying presence.

\section{Mass Media \& Psychocentrism}

Mass media, inclusive of media technologies such as the internet, functions as a fluid space of socially shared knowledge or (perceived) truths, in which public discourses are actively made and remade, providing a "complex epistemic context" to analyze normative constructions (Ohlsson, 2018, p.298). The presence of contemporary anti-stigma or awareness campaigns within mass media operate as discursive mechanisms to produce and reproduce dominant discourses related to madness and distress (Oute et al., 2018), in which biomedical constructions and psychocentric perspectives (Rimke, 2016; see also Rimke, 2011; DeFehr, 2016; Dej, 2016) dominate within the mental health paradigm (Beresford, 2019). According to Dej (2016), "psychocentrism is a governing neoliberal rationality that pathologizes human problems and frames individuals as responsible for socially structured inequalities" (p.117) according to a "human deficit model" (Rimke, 2016, p.8). Considering the dominance of neoliberal rationality within the literature reviewed, the constructed "ability" to recover or overcome mental health issues or distress successfully through clinical psychiatric treatment (Corrigan et al., 2014; McGinty et al., 2015; Martinez et al., 2017; Peters, 2017), is achieved solely through individual perseverance or overcoming stigma, reflective of neoliberal governmentality (Rimke, 2016) and the (mechanizing) discourse/ technology of responsibilization (Foucault; 1967; Teghthsoonian, 2009). According to Rimke (2016), "neoliberal governmentality manages human subjectivities as 
an ensemble of social forces that both construct and reinforce individualization and privatization" (p.7), facilitating the dominance of therapeutic culture and the pathologization of distress (Joseph, 2019; Rimke, 2016). Responsibilization is a primary technology of neoliberal governmentality (Peeters, 2017), in which the individual self-regulates their behaviour according to neoliberal state interests and supports the shift of social responsibilities from the welfare state to the individual.

Within this dominant framework, the presented usefulness of mass media awareness campaigns such as Bell's Let's Talk, or CAMH's Transforming Lives and Mental Health is Health initiatives are in their alleged ability to normalize stigma (Vido, 2019) and increase individual interactions with dominant clinical mental health or psychiatric institutions across diverse populations (Booth, Allen, Bray Jenkin \& Shariff, 2018; Cheng, Benassi, de Oliveira, Zaheer, Collins, \& Kurdyak, 2016; Evans-Lacko, Kohrt, Henderson \& Thornicroft, 2017; Vido, 2019). The constructed efficacy of these campaigns examined in the literature exists within a psychocentric framework of analysis and relies on dominant, psychiatric constructions of madness and distress (Khenti, Bobbli \& Sapag, 2019), to position awareness campaigns as positive mechanisms simply facilitating social change, which plays out on the individual and their behaviour. The efficacy of an anti-stigma campaign is often measured according to statistical increases in treatment seeking behaviour (Biringer et al., 2016; Eiroa-Orosa and Lomascolo, 2018; Hanisch, Twomey, Szeto, Birner, Nowak \& Sabariego, 2016; Henderson, Robinson, Evans-Lacko \& Thornicroft, 2017) and increased institutional "safety seeking" or engagement with "criminal justice” and psychiatric systems (Peters, 2017). Analyses of campaigns in our local context are limited and there is currently no academic literature analyzing 
CAMH's Mental Health is Health initiative or its Coping with COVID-19 series, from any standpoint.

The contributing disciplines and institutions throughout the literature discussing antistigma/awareness campaigns are predominantly psychiatry, psychology, public health policy studies, community health studies, sociology, social work and nursing, as well as contributions directly from CAMH and the Institute for Clinical Evaluative Sciences (Cheng et al., 2016; Booth et al., 2018). Common research methods used throughout the available literature include purposive theoretical sample surveys (Collins et al., 2019; Crowe and Averitt, 2015; Martinez et al., 2017; Pescosolido et al., 2019) and questionnaires (Carey et al., 2019; Deb et al., 2019; Eiroa-Orosa and Lomascolo, 2018; Khenti, Bobbli \& Sapag, 2019;) as primary methods of data collection. Focus groups were used in one study (Montgomery et al., 2018), however there is a questionable absence of qualitative research or complex inquiry examining the individual experience of awareness campaigns and the production of identity or self, particularly in relation to madness. The politics of evidence (Denzin, 2017) which contribute to the primacy of evidence-based research in the context of mental health support a positivist paradigm by privileging quantitative methodology and methods to provide large quantities of data. In line with positivism, quantitative methods dominate the literature and the high prevalence of psychiatric journals and institutions (including $\mathrm{CAMH}$ ) with a high likelihood of interest in the promotion of established campaign "efficacy" facilitating and presenting "objective" research throughout the literature are curious, if not entirely suspect.

According to Rimke (2016), "neoliberalism can be understood as a series of pro-market and pro-corporate policies that seek to integrate state and market operations to benefit the interests of transnational corporations and the wealthy" (p.6). According to neoliberal positivism, 
socio-historical context is a potential pollutant of objective truth (Carter and Little, 2007) and irrelevant to the scientific method which seeks to extrapolate an objective reality. The lack of socio-historic context or reflexivity throughout the research is concerning. According to Hunter (2002), "neoliberal positivists serve the interests of the dominant group by using science to create a reality" (p.129) whereby an individualized, psychocentric/eurocentric approach to difference garners support for medical intervention. Some of the reviewed literature seemingly uses Mill's "abstracted empiricism" (in Denzin, 2017 p.11) to establish a correlation between mental health service use and wellness (Biringer et al., 2016; Booth et al., 2018; Cheng et al., 2016; Eiroa-Orosa and Lomascolo, 2018). The literature also includes the promotion of methodological individualism (Charmaz, 2017) or motivation as an explanation for the experience of mental health disparities and the inability to seek or access dominant services, merely operationalized through stigma. This perception in which you simply need psychiatric services as a gateway to wellness lacks any consideration for subjugated epistemologies, Indigenous and constructivist worldviews, critical and anticolonial theories or the complex, confluent realities of structural violence maintaining the authority of the western psy-complex (Joseph, 2015; Rimke, 2016). As Ameil Joseph (2019) indicates, "psy knowledge, expertise, and its positioning as superior is imbricated with historical colonial projects of white supremacy and has become an overwhelming mode of domination" (p.15).

Rimke (2016) refers to the western psy-complex and the "psy-industry" (p.5) as encompassing all health and helping disciplines operating within a neoliberal theoretical framework and positivist epistemological paradigm using "biomedical explanatory modalities" (Kilty \& Dej, 2018, p.2). The lack of explicit critical attention within the research to structural, contextual realities or the fluid complexity of identity (Khenti et al., 2019; Biringer et al., 2017), 
silences diverse experiences of violence within the psy-complex, falsely simplifying recovery as a universally accessible (or ideal) singular trajectory across difference (Peters, 2017) and in turn, privileges the neoliberal psy agenda (DeFehr, 2016; Rimke, 2016). In assimilationist epistemology, diversity is theorized as a "barrier to progress" (Hunter, 2002, p.125) in which the construction of a "successful immigrant" is defined according to assimilative principles and conformity to white rationality through "bootstraps discourse" (p.126), in which the assimilated immigrant is positioned as the knower. In the context of this research, in which the successful or recovered patient (Cheng et al., 2016) is the knower and holds legitimacy or personhood within neoliberal discourse, the personal experience of recovery is valued as knowledge and positioned as evidence of successful recovery trajectory through similarly prescribed bootstraps discourse (Hunter, 2002; Cheng et al., 2016). The centering of this knowledge or lived experience from the recovered patient (Cheng et al., 2016) serves neoliberal interests and is often the idealized source of data among the research to construct claims to campaign efficacy; where decreased social stigma surrounding mental health magically supports increased psychiatric service accessibility and produces successfully "recovered" (or economically viable) normative bodies (Peters, 2017), without attention to highly nuanced structural realities. The primacy of the recovered patient as knower in lived experience narratives is evident in CAMH's Coping with COVID-19.

In Biringer, Davidson, Sundfør, Ruud \& Borg (2016), responsibilisation individualizes, pathologizes and disables research participants who allegedly "sought help due to various mental health issues that had interfered with their lives and created disability and suffering." (p.505). The research participants construct "good mental health" (Montgomery, Wilson, Houghton \& Harper, 2018) and recovery through primarily financial terms such as "being able to work, get a job and avoid getting a disability pension" (Biringer et al., 2016, p. 511). Positioning 
"good mental health and well-being" as vital for "society is to grow and prosper" (Montgomery et al., 2018, p.112) is a theme across the research in which economic viability is synonymous with recovery (Biringer et al., 2016; Corrigan et al., 2014; McGinty et al., 2015; Martinez et al., 2017) and ultimately serves neoliberal interests (Rimke, 2016).

There is an absence of literature which evaluates campaigns from a critical standpoint, troubles their perceived efficacy and interrogates their relationship to sanism, racism and colonialism. The role of these specific media campaigns in Canadian context are not positioned as discursive mechanisms, in which their operationalization of various technologies requires intense interrogation, given their ability to infiltrate, permeate and indoctrinate the masses. In a modified critical discourse analysis of the CAMH's Coping with COVID-19's people with lived experience testimonials, I set out to address the absence of subjugated knowledges and voices within its white, psychocentric constructions of mental health or wellness (Leblanc and Kinsella, 2016; Rimke, 2016; Joseph, 2019) embedded within psy discourses and suspended within the context of colonialism. Awareness campaigns propagated through mass media are touted as actively normalizing (Vido, 2019) and pose as counter-discourse. As McKenzie-Mohr and Lafrance (2017) indicate, not all counter-narratives are liberatory and I would argue from a critical standpoint that the positioning of this awareness campaign as a counter narrative from people with lived experience sharing their methods of "coping" is instead operating as a thinly veiled mechanism to normalize and promote white, psychocentric, colonial master narratives, psy institutional violence and white supremacy (Joseph, 2019; Peters, 2018).

Considering this literature review and the absence of critical inquiry in academic literature examining contemporary anti-stigma/awareness campaigns conducted by the dominant psychiatric institution in Toronto, CAMH, I planned to examine the discourses (re)produced in 
this media, drawing from critical and postcolonial theories, with particular attention to confluence. There is no available analysis of lived experience testimonials, specifically produced in our local context during COVID-19. I intended to investigate what discourses are (re)produced through CAMH's Mental Health is Health: Coping with COVID-19 awareness campaign, how madness is (re)constructed through testimonials of people with lived experience and consider what social "project" these discourses/technologies are serving? 


\section{CHAPTER 2. THEORETICAL FRAMEWORK}

I initially entered into this work with the intention to draw from critical race theory, anticolonialism and mad studies with an emphasis on intersectionality in my developing framework. Due to the complexity and tensions outlined in the following, particularly related to the concept of intersectionality (Joseph, 2015), I have chosen to work from a theoretical framework in the style of Ameil Joseph (2015). I will primarily draw concepts from postcolonial theory, critical race theory and antipsychiatry with particular attention to confluence, in which "an analysis of confluence holds as complicit our practice of relying on an interlocking analysis that examines already determined analytical categories in relation to a phenomenon" (p.25) and complicates any claim to "anti"-colonial/racist/sanist/oppressive frameworks. I will draw from the concept of psychocentrism and its investigation of "the ways in which neoliberal populations are governed according to psy knowledge" (Rimke, 2016, p.8) and the citizen-subject is constructed/ discursively produced, positioning it as one of the "processes and technologies of dehumanization" (Joseph, 2015, p.35) serving the colonial project of white supremacy (Joseph, 2019) through the maintained dominance of the psy-complex and agenda. As Joseph (2019) aptly indicates, "this is neither about sanist, racial or criminal, colonial, and eugenic ideas nor systems individually, but about all of them as a confluence" (p.10) and their operationalization of projects of dominance. As I work from a position in which I seek to embody anticolonial, antiracist and anti sanist perspectives, Joseph (2015) necessarily complicates and outlines the complex contradictions within such sentiment. I will draw from the following theories, however I will maintain the skepticism and suspect presented by Joseph (2015) to frame my analysis.

\section{Why not Mad Studies?}


According to Gorman and LeFrançois (2017), mad studies "takes social, relational, identity-based, and anti-oppression approaches to questions of mental/ psychological/ behavioural difference, and is articulated, in part, against an analytic of mental illness" (p. 109), while centring the knowledge of lived experience. Although my initial inclination was to draw from mad studies as I resist the analytic of mental illness as described, I acknowledge mad studies as supporting my entrance into this space of theory, however its problematics, particularly located in its politics of lived experience, are troubling (Joseph, 2019, Rovet, 2017). Joseph (2019) contends "the values, principles, and standards for appreciating lived experience within Critical Disability and Mad Studies have (re)produced a general neglect for the kinds of dehumanization and violence experienced by racialized and Indigenous groups" (p.9). The whiteness of critical mental health, Critical Disability (white disability) and Mad studies as well as its participation in the erasure of racialized and Indigenous experiences (Joseph, 2019) is well documented (Bell, 2010; Grant, 2013; Gorman, 2017; Rose \& Kalathil, 2019 Sweeney \& Beresford, 2019; Voronka, 2017). In the end, as a theoretical framework, drawing from mad studies is simply not enough; particularly in its relationship to the colonial project and white supremacy (Joseph, 2019), despite alleged resistance to the psy-complex.

\section{Antipsychiatry}

I will draw from antipsychiatry and critical perspectives in mental health when disrupting the construction of "mental illness" as a pathological model of biomedical, individual deficit and position it as a social construction (Foucault, 1967; Menzies, LeFrançois \& Reaume, 2013; MacDonald, Charnock \& Scutt, 2018). Antipsychiatry has roots in the $18^{\text {th }}$ century and picked up as a social movement in the 1960s and 1970s (Berlim, Fleck \& Shorter, 2003; Pajević \& Hasanović, 2017), criticizing and rejecting the perceived legitimacy and dominance of 
psychiatry, its institution, practices and biomedical constructions of madness and distress (Burstow, 2015, Reiss, 1972; Whitley, 2012). Bonnie Burstow (2015), in line with Foucault (1967; LeFrançois, Menzies \& Reaume, 2013) positions psychiatry as a "regime" which "as a whole is epistemologically flawed and ethically unacceptable" (p. 227), operating as "a key enforcer of neoliberal values" (MacDonald, Charnock \& Scutt, 2018, p.104), in which acts constructed as treatment is violence facilitating social control.

With intentions to normalize madness (Baklien \& Bongaardt, 2014) and position distress as a response to social conditions (LeFrançois, Menzies \& Reaume, 2013), antipsychiatry exists to resist psychiatry's diagnostic frameworks and legacy of dehumanizing violence (Joseph, 2015). The foundational work of Erving Goffman and R.D. Laing, who conceptualized distress as an individual performance, bound to socio-historical context (MacDonald, Charnock \& Scutt, 2018), Thomas Szasz who claimed mental illness as a "myth" (Joseph, 2015, p. 1024) and Franco Basaglia, whose perspectives on the asylum were its inhumane methods of confinement and control (Joseph, 2015, p.1024) inform its legacy and contemporary perspectives. As with most critical inquiry, antipsychiatry often experiences discrediting and dismissal for its lack of appeal to positivist empiricism (MacDonald, Charnock \& Scutt, 2018), highlighting its propensity to centre qualitative research and narratives of lived experience. Although antipsychiatry addresses the function of psychiatry as a violent mechanism to reproduce neoliberal values and engages in resistance to the social control of its institution, my caution and hesitation of its exclusivity (particularly within its identity politics and emphasis on lived experience) is notable and in line with Guterres' (2017) critique of its white dominance and practices of exclusion. Although antipsychiatry informs my work in its emphasis on power and systems of domination related to the psy-complex, its reliance on a "eurocentric 
conceptualization of history" and "preclusion of historical attention to colonialism" or complicity to colonial projects as Joseph (2019, p.1022) indicates, is indeed troubling.

\section{Postcolonialism}

Postcolonialism "refuses to rely on knowledge of totalized ideas of difference in which someone else can possess expertise" (Joseph, 2015 p.26) and acknowledges the eurocentrism of psychiatric discourse and the psy-complex. I will use postcolonial critiques of psychiatric discourse to inform my discussion in the style of Ameil Joseph (2015), using confluence to contextualize content suspended within the complex legacy and constituting reality of colonialism. According to Joseph (2015), postcolonialism requires the interrogation of the projects of colonial taxonomy, which are conducted according to constructed categories of human deficit, while acknowledging the "dehumanizing technology of moralizing and civilizing therapies" (p.1038) propagated through the psy-complex, developed to operationalize these imperial taxonomic projects, reinforce a colonial social order and "rationalize violence" (p.1021). Joseph (2015) further encourages the requirement of all critical theories with social justice goals to intensely engage with the discursive technologies and practices of colonialism, which are designed to reinforce eurocentrism and colonial rule, are enmeshed within contemporary experience and transcend issues of structural discrimination or inequity alone. This required analysis informs my framework when considering the direct relationship between contemporary constructions of madness within the psy complex as necessarily confluent with colonialism (Joseph, 2015), in what Strakosch (2015) terms the entwined, "facilitative relationship" (p.170) of neoliberalism and colonialism.

\section{Confluence}


Ameil Joseph (2015) outlines a study of confluence as "focus(ing) on the how and the why, the practices and technologies and the social relations, thereby revealing a project" (p.26) versus an analysis of interlocking systems. Turning attention to the discursive technologies and practices which, suspended in fluid relations and time specific, "merge together at a similar point or juncture" (Joseph, 2015 p.28) reveal their service to a common project. This understanding informs my analysis of the discourses used to (re)produce normative constructions of the mad subject within CAMH's Coping with COVID-19's lived experience with mental illness testimonials in service of a common colonial project of white supremacy. As Ameil Joseph (2015) quotes Nadia Kanani (2011), "there are few studies that consider the intersections between race and madness, and fewer still that locate these intersections within the social and political contexts of colonization"' (p.1025). It is through this perspective I will excavate discourses to reveal the technologies and practices within this campaign. 


\section{CHAPTER 3. METHODOLOGY}

\section{Critical Discourse Analysis (CDA): language as social practice}

Jennifer Poole once told me, "discourses are like starlings" (personal communication, 2019). Such an apt visualization of their formation as fluid, fast, complex and mutually constitutive. I'd also say their formation, so beautifully reminiscent of an unarticulated, infinite trajectory of evolution, speaks to the reality of discourse as similarly infinite yet temporally bound, operating in continual confluence. According to van Dijk (2002), discourse operates "as the preferential site for the explicit, verbal formulation and the persuasive communication of ideological propositions" (p.17). Ideologies are "foundational beliefs" of social representations that are considered "the basis of discourse and other social practices" (van Dijk, 2006, p.116). In particular, critical discourse analysts seek to extrapolate the discursive structures and strategies which operationalize/(re)produce or resist particular relations of power, power abuse, dominance and injustice (Nonhoff, 2017; van Dijk, 1993), critiquing/unmasking power and ideology from a particular political, oppositional standpoint (Fairclough, 2010; Nonhoff, 2017; van Dijk, 1993; van Dijk, 2005). Critical discourse analysis requires a political/social ethic on part of the researcher to possess "critical adequacy" (van Dijk, 2005, p.19) and an explicit, oppositional stance to the status quo. The far reaching "productive capacities" of discourse, according to Dyson and Gorvin (2017, p.781), play out on individual bodies as technologies (Foucault, 1967) to structure the sense of self, subjectivity and construct social realities, while enacting, reproducing and legitimating power and dominance through communicative forms. CDA also questions the reproduction and legitimation of power through patterns of access to discourse (van Dijk, 1994) and its distribution, the roles of the elite in its production as well as strategies of legitimacy (van Dijk, 1993) and manufacturing consent (Chomsky \& Herman, 1988; van Dijk, 
1994). To be critical is to be political (van Dijk, 1994) and to conduct a CDA, an explicit socio political standpoint is required (van Dijk, 1993).

Conducting a CDA requires the study and critique of a social problem such as racism or sanism and examining the role of discourse in the "(re)production and challenge of dominance", which is "the exercise of social power by elites, institutions or groups that results in social inequality" (van Dijk, 1993, p.250) and social control. Analysts seek to identify the "structures, strategies and properties" which function to reproduce dominance located in communicative modes (van Dijk, 1993) that are manifest institutionally and structurally. van Dijk (2008) encourages us to examine context as well as text and talk in our analyses as "text in context" (p.826). Modes of communication (text, talk, images) and context must necessarily interact "to generate social meaning" (Nonhoff, 2017, p.8) and therefore require an interactive analysis that examines all moving parts.

CDA operates with social goals as a social practice (Nonhoff, 2017), in that it is complex, fluid and interacts with analyst subjectivity. Theorists Faiclough (2010), Wodak and Meyer (2009) and Van Dijk (1993) refer to emancipation and enlightenment as crucial components of CDA, which necessarily differentiate it from the radical relationality of Foucault and Foucauldian discourse analysis- which conflicts/contrasts with critical theory (Nonhoff, 2017). Although I draw some theoretical concepts from Foucault and CDA relates to Foucauldian fundamentals, it is crucial to emphasize my entire analysis is conducted from a critical framework and political standpoint in which emancipatory social goals are morally paramount and can be realized. van Dijk (1994) encourages analysts to question "to whom will research results be relevant and useful" and "will this be used to empower and support challenges to dominance" (p.435)? Solidarity, or "taking sides for the oppressed and excluded" (Nonhoff, 
2017, p. 7) is necessary, while the requirement to share analyses and findings to expose the very institutions, elites and beneficiaries of dominance are required to achieve emancipatory goals- it "must be effective" (van Dijk, 1993, p.20). As I am drawing from critical and postcolonial theories, my position in this work is to entirely challenge dominance and expose the production of white supremacy in the content I will be analyzing.

\section{Why CDA?}

CDA asks us to consider how power is (re)produced in the context analyzed with the great question underpinning all inquiry, "whose interests are being served" (Janks, 1997)? My interest in critical discourse analysis stems from weeks of debating and navigating qualitative research methodologies at the beginning of this program. I questioned myself over and over, if I would be engaging in risk, exploitation or any one of the many violences which occur within

research. There is always risk for violence and at the time, nothing would sit right with me and I didn't feel equipped to "go there". As Janks (1997) succinctly questions, "whose interests are being served" underpins all my curious inquiry and the potential of CDA to interrogate and satisfy my approach was interesting. To excavate and interrogate the ideological and structural violence embedded in our communicative forms is fascinating and terrifying; I was eager to investigate the systems which dominate and the discursive technologies which co-construct our realities, that have caused so much pain and suffering in society and in my own life. I am interested in the construction of madness, who or what project is served in its construction and which technologies of self are (re)produced in mass media, which in the end contribute to my own identity construction.

\section{Data Collection}


CDA does not offer a singular framework or rigid methodological process, instead it encourages working from a similar perspective (ie: critical theory) across disciplines (Amoussou \& Ayodele, 2018). I will be drawing from van Dijk's (1993) approach, with particular attention to power as control (Amoussou \& Ayodele, 2018) and multi-media data incorporation (Wodak \& Meyer, 2009), Fairclough's (2010) approach and attention to the "discourse-power-ideology relationship" (Amoussou \& Ayodele, 2018, p.14), while alluding to Wodak's (2009) emphasis on socio-historic context in my emphasis on colonialism. The lack of a rigid framework for data collection and no sampling method leaves room for uncertainty but creativity. Wodak and Meyer (2009) relate CDA to grounded theory, in which data collection is not a "step" required to be completed prior to analysis, leaving flexible room for considerable (re)interpretation and emphasizing an interactive relationship between analyst and data, changing depending on the information, ideas or inklings that come about throughout the process.

I used the nine "lived experience" testimonials/stories within CAMH's Mental Health is Health campaign's Coping with COVID-19 initiative to examine the discourses (re)produced in this specific, local context. My decision to analyze a campaign from Toronto's dominant clinical mental health institution is partially informed by its far reaching, hegemonic influence in clinical practice and research as "the largest mental health and addiction organization in Canada" and "one of the world's leading research centres" (Centre for Addiction and Mental Health, 2020), as well as its permeability in mass media and common dialogue as the go-to resource when in distress. The Coping with COVID-19 initiative was launched in response to the pandemic of COVID-19 we are currently living in and is indicative of the dramatic uptick in dialogue related to "mental health", "stigma" and "coping" with crisis at this juncture. It was through an initial interest in analyzing discourses through social media which brought me to this initiative, where 
the hashtag \#mentalhealthishealth dominates local Twitter content when inputting \#mental health and \#covid in their search engine. I examined the dominant hashtags present in my local context from March 2020-June 2020 containing “\#mentalhealth” and “\#covid”. The hashtag “\#mentalhealthishealth" was common and led me to its direct affiliation with the Mental Health is Health initiative. Accompanying hashtags included \#camh, \#camhnews, \#ApartNotAlone, \#bewell and \#SickNotWeak. Investigating this phenomenon led me to notice the increased presence of CAMH as a major content producer and their promotion of the Mental Health is Health awareness campaign in their social media, including the lived experience testimonials within Coping with COVID-19. These nine testimonials with accompanying images are being promoted through social media and offer a discursively rich focal point for analyzing contemporary constructions of madness and "coping", propagated during this juncture of COVID-19.

Considering my methodology includes the analysis of public texts available on the internet, I was not required to submit to REB for approval. To further prevent harm, I will not be using names or other major identifiers in my discussion, simply referring to each data set as a "Case" numbered 1-9. You will find the testimonials available here for context: https://www.camh.ca/en/health-info/mental-health-and-covid-19/coping-with-covid-19.

\section{Analysis}

\section{Bias and error: context, COVID-19 and stress}

The inability to consistently attend to the research over recent months facilitated a fragmented approach to the data, as I would necessarily visit and revisit my work sometimes days and weeks at a time. Given this constant re-engagement with the material, I feel it is necessary to disclose that this process was sporadic but intense and it has completely influenced 
my interpretation. Given the context of COVID-19 and the stress that every human is currently enduring, this reality and its stress impacted my analysis. If anything, it has allowed for greater attention to certain aspects of the work as time away from text alters perspective, but as all the parents of young children during COVID-19 know, this new reality of juggling multiple tasks within the confines of a noisy home has proven challenging.

Drawing from Fairclough's model, which includes an interactive, threefold dimension of discourse, there is a framework to examine the text/media, consider its method of production and its socio-historical context (Janks, 1997). According to Wodak and Meyer (2009) in the spirit of van Dijk's (1993) socio-cognitive approach, a few suggested linguistic indicators to look at in analysis of social power include "stress and intonation"; "word order"; "lexical style"; "topic"; "hesitations"; "rhetorical figures"/figures of speech and "speech acts", etc. (p.28-29). This approach also suggests analyzing "topics", "local meanings and implications", "subtle formal structures", "local discourse forms" and "context" (Wodak \& Meyer, 2009 p.29). As this is a modified CDA with a limited data set of nine texts with accompanying images, I will selectively but consistently use some of these analytical processes to inform my approach.

A notable limitation of this research is the limited text used as data and although discursively rich, the testimonials were not necessarily robust. I began with an overview of the testimonials, their text and images, where I documented my overall impressions and inclinations. In line with Poole's method as interpreted by Leblanc (2017), I identified key words and concepts which spoke out according to these linguistic indicators and wrote them down, creating categories. These categories organized the words and concepts pulled through subsequent rereads to extract emerging discourses. As indicated by Leblanc (2017), Poole uses reflexive journaling and audit trailing in their methodology, which inspired my own use of a journal as a 
reflexive thought and note record throughout the process to encourage "methodological selfconsciousness" (Charmaz, 2017, p.35), particularly in detailing my analysis (J. Poole, personal communication, February 2020). I considered how I was feeling while I engaged with data and checked in with my body regularly throughout the process, recording reactions. I also colour coded each theme and arranged words/phrases according to their frequency of use.

This methodology is not without tension and it is necessary to be critical of its eurocentric roots. As Joseph (2019) indicates, “critiques themselves can also re-inscribe foundational, irreconcilable problematics via their contributions" (p.2). Ultimately, I am a white body engaging in a white methodology (P. George, personal communication, November $14^{\text {th }}$, 2019) seeking to analyze white supremacy and there is conflict and compounding tension within this process. I carry these conflicts and tensions throughout my work, questioning the possibility in which I am simply reproducing all I seek to resist. This research has been conducted entirely from the comfort of my desk, through my lens, and although I commit to considerable reflexive analysis, I question its efficacy and I acknowledge the risk (or likely inevitability) of armchair theorizing/slacktivism. I question what research is critical, let alone radical, without activism and the difficulty of claims to anticolonialism when the methodology is so far removed from the principles of anticolonial research (Carlson, 2016).

As Macias (2015) indicates, "research itself is a political and social activity located within social power relations that necessarily implicate us" (p.222). I am seeking to resist settler colonial violence in my research as a governing rationale from the outset, however I also question its possibility without radical attention to our inevitable complicity in its formation and (re)production (Joseph, 2015, p.24). I am reminded of Joseph (2015) and their necessary call of attention to our inevitable embodiment and suspension within transcendent colonial violence, in 
which the transparent acknowledgement of my complicity is absolutely necessary yet precludes us all from any "position of anti" (p.24). We are all suspect, suspended within fluid confluence of colonial systems, trajectories and histories, which play upon and within our bodies to produce an experience which is both infinite yet temporally bound (Joseph, 2015; 2019). Joseph (2015) continues to encourage shifting our gaze to analyzing relations and operations of power and their common projects, without reliance on identity categories or intersectional and interlocking analyses, which are (re)produced through the very means of violence we seek to resist. It is through this lens, which complicates all "anti" theoretical frameworks which are produced through and dependent upon the violent colonial systems they seek to resist, that I will draw from Joseph's (2015) theory of confluence in my analysis and shift the subject of attention to technologies, processes and the common project of white supremacy evident in discourses used to construct madness, while entirely positioning "myself and my study" (p.27) as complicit. I am questioning who has been excluded and who has been invited into institutional spaces of disclosure and information sharing (McKenzie-Mohr and Lafrance, 2017) in this context, at this juncture and for what purpose. 


\section{CHAPTER 4. FINDINGS}

In this section I will outline the findings from my analysis of nine Coping with COVID19 lived experience testimonials. Throughout the discussion I will refer to each data set as "Case 1-9". The discourses which I extracted from the data are as follows: The first identified discourse is "responsibilization: individualism and necessary service to others". The second identified discourse is "successful recovery is a return to work: neoliberal productivity and enterprise". The third discourse is "mental health is health: sane-healthism". The fourth discourse is "madness as deviance, violence and dangerousness: the continued confluence of mental health and carceral systems", while the fifth discourse is "we are all in this together: individualized collectivism". The sixth and final discourse is "lived experience and medicalization: psychiatry still knows best". All of the identified discourses interact and weave together throughout the data, often symbiotically emerging in single phrases, existing and working in conjunction as technologies of the same colonial project.

\section{"A CAMH extended family member": the good, mad subject}

On the initial CAMH webpage with hyperlinks to the testimonials, each author is described as a "member of the CAMH extended family-specifically people with lived experience of mental illness who have made a commitment to mental health advocacy" (O'Malley, 2020, para.1), with the exception of Case 9, who is described as a "front line psychiatrist in CAMH ED" and "Clinician Scientist at the CAMH Institute for Mental Health Policy Research and Education Administrator at the Gerald Sheff and Shanitha Kachan Emergency Department" (Zaheer, Case 9, 2020). This testimonial, although not an individual with admitted "lived experience of mental illness" but a CAMH psychiatrist, will be included in my analysis as it is presented as such, whereby its peculiar placement hidden among the lived experience 
testimonials is suspect and arguably insidious. The expertise presented in the psychiatrist's testimony in Case 9 is implied and remains uninterrogated, where its' necessary placement within the data conjures sentiment not only reflective of deep, historic power imbalances, violence and testimonial injustice propagated within the psychiatric apparatus (Leblanc \& Kinsella, 2016), but undermines the presented validity of the remaining eight cases of lived experience. It's as though all authors are presented as having "some expertise in how to get through hard days" (O’Malley, 2020, para. 2) however they must be supported by the opinion and narrative of an actual expert, presented in this case as a CAMH psychiatrist who through this equation of knowledge and validity in their placement among the testimonials, showcases the epistemic gatekeeping and moderating power of psychiatry through this presentation of "lived experience" without full participation (Leblanc \& Kinsella, 2016). The inclusion of a psychiatrist's narrative within this collection, without explicit articulation of its entire difference as not representative of lived experience, is entirely suspect and re-entrenches the hegemony of psy-knowledge and authority under the guise of lived experience discourse, operating as a "technology of identification/representation" to "maintain colonial, eugenic violence" (Joseph, 2019, p. 2). This subtle subjugation immediately sent a visceral response throughout my body, as if what is actually being said is "we'll listen to you and your lived experience, although it's mainly lip service unless we can profit off your testimony, but let's hear what your 'handler' has to say", in line with the discourse of "psychiatry knows best". Visceral reactions abound throughout my experience with this research and my body often guided me to subtle, nuanced understandings of the data. I learned to pay attention to my body when engaging with social acts, even those as seemingly simple as reading text, as it served to provide as a point of inquiry demanding my reflexive interrogation. It seems the body can detect things on a level I was 
previously unattuned and I tried to engage in this, bringing a somatic element to my discourse analysis as a form of resistance to positivism. To my fellow students, follow your body. Those visceral reactions are in themselves, knowledge. I will discuss this further in the recommendations chapter and expand on the potential of visceral reactions as methodology in critical discourse analysis.

The lived experience of each author in the data is framed as expertise through their presented relationship to CAMH and adherence to prescribed notions of "advocacy" as well as their identification with "mental illness", as per its psychocentric construction propagated by the psy-complex. Each selected author has a direct or implied relationship to CAMH often described in their testimony, emphasizing "the role CAMH had played in helping them through their journey" (Pascal-Thompson, Case 7, 2020, para.1), such as when they "ended up at the CAMH emergency department" (Elliot, Case 1, 2020, para. 1), were "an Electroconvulsive Therapy (ECT) and Repetitive Transcranial Magnetic Stimulation (rTMS) patient at the CAMH Temerty Centre for Therapeutic Brain Stimulation" (Hofer, Case 8, 2020, para.1) or "named a CAMH difference maker" (Buchanan, Case 3, 2020, para. 3; Farrant, Case 2, 2020, para. 2). The promotion of various $\mathrm{CAMH}$ programs and procedures throughout the data is glaring. For example, in reference to Repetitive Transcranial Magnetic Stimulation, Case 8 states "after decades of dealing with mental illness, Shelley says she can now predict fairly accurately when her mental health is starting to deteriorate again and it is time for another maintenance treatment of rTMS" (Hofer, case 8, 2020, para. 2). As Joseph (2019) indicates, "relying on lived experiences and stories for marketing purposes repositions and recreates social relations of exploitation that also feed progress discourses that transformation is occurring" (p.6). The cooption of lived experience in this context is indeed suspect, as is its explicit propagation of 
CAMH as a saviour-like institution and its offered psychiatric procedures through the exploited "success stories" of its selected CAMH family members and "change makers", under the guise of reducing stigma, is difficult to deny. The previous quote from Case 8, in which "Shelley says she can now predict fairly accurately when her mental health is starting to deteriorate again" is reflective of the following identified discourse of responsibilization, in which it is an individual's personal responsibility to surveil themselves and pre-emptively engage in "maintenance treatment" for their prescribed mental illness.

\section{Discourse 1: Responsibilization: individualism and necessary service to others}

In line with the reviewed literature, neoliberal rationality dominates the lived experience testimonials and responsibilization discourse appears across the data. As a primary technology of neoliberal governmentality (Peters, 2017), responsibilization shifts social responsibilities from the state to the individual, in this case constructing the ideal "CAMH family member" (O'Malley, 2020, para. 1) or mad subject as one who simultaneously embodies individualism in their own care or wellness and actively engages in service to others. Repeated statements such as "this is the time when you have to learn to be kind to yourself" (Case 3, Buchanan, 2020, para. 11) and "learn to be kind to yourself" (Buchanan, Case 3, 2020, para. 1) indicate the constructed responsibility of the individual to self-surveil, self-regulate and embody dominant constructions of "kindness" in neoliberal context, whereby "you have to have extreme self-love" (Pendenque, Case 5, 2020, para. 11). Inferred in these statements are the absolution of state responsibility or anyone outside the self to bestow any "kindness" or civility to the mad subject, contrasting with the simultaneous responsibilization of the mad subject in supportive service to others. "Extreme self-love" implies an absence of external love without contest and I would argue this also reflects a permissive stance on the continued, violent marginalization of mad bodies. In this context, I 
would also argue "kindness" is conflated with civility but also passivity; in which dissatisfaction or outrage with structural processes and psychocentric violence is quelled through a shift of focus to individual responsibility to simply "love" one's self.

"Making do with what you have" (Christina, Case 4, 2020 para. 1) and the use of "how I manage to keep my head above water" (Christina, Case 4, 2020 para. 2) as figures of speech in the data is also particularly telling. Their promotion of responsibilization and individualism in which "making do" could be considered a neoliberal trope and the continued absolution of the state from social welfare is also reflected in the implied drowning of an individual "keeping their head above water". Drowning implies lack of external assistance, lack of structural context and the emphasis is placed upon the individual to simply save themselves, treading by any means necessary to survive. The quotes "I just worked on my training to calm myself down" (Farrant, Case 2, 2020, para.5) and "I am applying my mental illness to my life instead of trying to fight it" (Case 5, para. 8) are reflective of the common use of subjective terminology throughout the data to take responsibility for individual needs, in which "working" or "applying" is also reflective of neoliberal notions of productivity and commodification. The quote "I am applying my mental illness to my life instead of trying to fight it" (Case 5, para. 8) presents an individualized, permanent or inescapable, psychocentric origin of "mental illness", implying necessary commodification of experience and distress to be constructed as resilient and achieve personhood as the "good, mad subject" or "CAMH family member". Case 4 states "we need to create to make ourselves feel better [emphasis added]" (Christina, Case 4, 2020, para. 9), indicating the necessary responsibilization of self according to the confines of neoliberal productivity, to find ways to simply "feel better". 
Necessary service to community members as a form of social responsibility for folx with lived experience is also evident in Case 3, in which the author indicates "I have a pressure to put on the superhero cape and save everyone" (Buchanan, Case 3, 2020, para. 6). Case 8 also states that during COVID-19, "because I am a mental health advocate I have been getting a lot of requests for support" (para.7). Outsourcing mental health supports to individuals with lived experience through peer support has been examined as a form of neoliberal commodification by Voronka (2017) and it seems as though the internalized responsibility to the community evident throughout the data may be similarly positioned as the commodification of lived experience. Case 1 also asks, in reference to their inability to engage in their typical community service activities now disrupted by the social distancing measures in place during COVID-19, in which they "try to be the kind one who actively helps those around me", they question "so who am I now?" (Elliot, 2020, Case 4, para. 4). The entanglement of community service and kindness with identity is common throughout the data. In Case 6 the author also notes, "what gets me out of my dark moods is service to others every time. I feel like I was put through my own personal hell to help others get through their tough times" (Siolkowsky, Case 6, para. 15). The productive application of lived experience to "help others" and the outsourcing of mental health supports to CAMH family members is reflective of responsibilization as a technology of the self and neoliberal governmentality (Rimke, 2016).

\section{Discourse 2: Successful recovery is a return to work: neoliberal productivity and enterprise}

The explicit or implied notion of "successful recovery" is evident across the data, as each author is constructed as recovered and their individual identity is constructed in relation to their "work", "career" or "profession" within their testimonial. The word "work" is used extensively throughout the data, as well as "make", "making" and "meaning". Case 3 "has made a go of it in 
the high-wire worlds of acting and film-making for much of her adult life. This despite [emphasis added] an ongoing history of anxiety, depression and suicidal ideation" (Buchanan, Case 3, 2020, para. 1). There is heavy implication evident in the word despite, not limited to the sanism of lowered expectations (Poole et al., 2012) or assumed contradiction of madness within the "high-wire worlds" of professionalism. Case 1 indicates due to COVID-19, "I have taken a leave from work" (Elliot, Case 1, 2020, para. 3) and "work is a form of therapy for me in its own way. It's where I find meaning" (para 7). The conflation of work with the good, mad subject is evident in the direct attribution of productivity to wellness or recovery. This is particularly evident in Case 1, who "attributes a large part of the success of her recovery to the ongoing support of her employer, which partnered her with a gradual return to work program" (Elliot, Case 1, 2020, para.2). The explicit, discursive framing of a return to work as successful recovery is also evident in the description of Case 5, which states "as a young man, he found himself homeless on the streets of Toronto until LOFT Community Services helped him turn his life around and he was able to embark on a successful career as a youth social worker" (Pendenque, Case 5, 2020, para. 2)

As George and George (2013) indicate, in the construction of market citizens as ideal citizens "it is up to individuals to continually refine their innate marketable skills as well as to acquire new ones in order to provide for themselves, their families and the state" (p.68). Case 3 indicates "we need to create to make ourselves feel better" (Buchanan, Case 3, 2020, para. 9). References to productivity and enterprise are furthered in Case 4, who indicates "while the pandemic has put a halt to many of her ambitious projects, she found a surprising silver lining that has allowed her new career as an artist to flourish even more than before" (Christina, Case 4, 2020, para. 6). This "silver lining" is in line with capitalist and neoliberal notions of productivity 
and economic viability, similarly reflected in Case 6, who applies this emphasis on enterprise to her diagnosed "mental illness", in which "she also talked about her transition to a new career as a professional organizer, which she says came directly out of her experience with depression, anxiety and obsessive-compulsive disorder (OCD)" (Siolkowsky, Case 6, 2020, para. 5). The "silver linings" of madness are presented as more than mere tropes but appeal to economic viability, in which the good, mad subject or recovered CAMH family member is predominantly defined by their return to work. When the author literally capitalizes on their lived experience as in Case 6, (which appeals to dominant constructions of obsessive-compulsive disorder (OCD) as stereotypically conflated with organization, worthy of analysis in itself) they are lauded. Case 6 comments, "suddenly I was an expert in crazy paranoia” (Siolkowsky, Case 6, 2020, para. 13). According to Joseph (2019), "within psy institutions, these (re)processed versions of recovery have come to mean you still are a biomedical problem but you can live a dreamy neoliberal existence achieving "satisfying and productive lives", "with a message of individualism, empowerment and choice" (p.5). When you return to work, you are considered economically viable (Peters, 2017) and in the context of COVID-19, Case 8 encourages us to "think about how bad it could have been compared to how bad it is" (Pascal-Thompson, Case 8, 2020, para. 4) and realize, “OK, I’m still working. I'm still healthy” (para.4).

\section{Discourse 3: Mental health is health: sane-healthism}

Healthism "is a pervasive ideology that equates health with purity, civility and morality" through an "individualized framework of risk and responsibility" (Scott, 2020, p.70). Healthism operates as a technology of the self, "making the 'good' and 'healthy' citizen... by inciting the desire within autonomous individuals to choose to follow the imperatives set out by health promoting agencies, and thus, take on the responsibility of changing their own behaviours 
accordingly" (Ayo, 2012, p.100). As CAMH (2018) indicates in its public awareness campaign, "because illness is illness, mental health is [emphasis added] health" (CAMH, 2020, "Giving Mental Health", para.1.). A confluence of healthism and psychocentrism occurs in this discourse, translating into a specific form of what I term "sane-healthism", or the conflated construction of saneness as health throughout the data.

The term "health" (independent of the phrase "mental health") is used extensively throughout that data, whether in direct conflation with recovery as in Case 1, "it took her most of a year to return to good health" (Elliot, Case 1, 2020, para. 2) or in direct reference to their specific methods to stay "mentally healthy" according to health consumerism, such as "have I eaten something healthy? Have I exercised? Am I getting a good nights sleep?" (para 5). Case 8 indicates "since she had her last treatment just a few months before the pandemic began, she says she is actually feeling mentally healthy so far, indicating a resilience that surprised even her." (Hofer, Case 8, 2020, para. 3). Health is also presented in conflation with "resilience" in Case 8 and "strength" in Cases 1 and 8 . Case 8 states, "I always used to think I was a weak person - the whole sick not weak thing. But this pandemic has reminded me that I'm actually a really strong person. Throw a problem at me when I am healthy and strong and I will step up to the plate and do anything I can." (Case 8, Hofer, 2020, para. 5), while Case 1 notes, "for others who are struggling with their mental health, I would suggest that they are stronger than they feel right now" (Case 1, Elliot, 2020, para. 9).

According to Ayo (2012), "healthism and neoliberalism mutually reinforces the vision of the responsible, entrepreneurial citizen" (p.100). This discourse operates in confluence with responsibilization within a psychocentric framework, constructing madness as inherently pathological and reinforcing biomedical constructions of distress through its conflation with 
health. Case 8 states in reference to COVID-19, “my mental health issues aren't necessarily caused [emphasis added] by situations like the one we are in now. I didn't grow up with any childhood trauma and I was a straight A student and I still had depression" (Hofer, Case 8, 2020, para. 4). The inferred appeal to psychocentrism in the previous example is obvious in its denial of situational or social determinants of distress, as is the direct equation of "mental" "emotional" and "spiritual health" with "physical health" in Case 3; "take the time to reflect during this downtime and work on your mental and emotional and spiritual health that we don't pay as much attention to when we are so focused on our physical health" (Buchanan, Case 3, 2020, para. 9). The discourse of mental health is health and sane-healthism frames each testimonial, as the overarching campaign motto is, of course, mental health is health.

\section{Discourse 4: Madness as deviance, violence and dangerousness: The continued confluence of mental health and carceral systems}

According to Joseph (2019), "the myth that people diagnosed with "mental illness" are dangerous or violent is a falsehood that is exacerbated by sanism within the media, within biomedical psychiatry and its affiliated or allied disciplines." (p.6). Across the data, madness is internalized and constructed according to this discourse, in which explicit articulations and implications of madness as deviance, violence or dangerousness are espoused and normalized. Case 8 indicates in reference to their distress symptoms, "I worked very hard to hide it because I learned very early that people felt uncomfortable around my tears. I wanted to protect [emphasis added] them" (Hofer, Case 8, 2020, para. 4). The perceived discomfort of others experienced by Case 8 in relation to their madness is indicative of deeply imbricated, negative constructions and implications, as well as the implied responsibility of the mad subject to navigate any external discomfort of their person in order to "protect" others. Protection implies violence. Case 4 
discussed their experience following a diagnosis of psychosis as, "I knew from then on that I wasn't right [emphasis added]" (Christina, Case 4, 2020, para. 2). The implied deviance from prescribed norms or saneness necessitating the "protection" of others operates to validate any (perceived) external discomfort and invalidate the mad subject as inherently pathological or dangerous. In a particularly telling quote, in which Case 6 allegedly "gave up a promising teaching career after losing her job when her administration learned of her depression diagnosis" (Siolkowsky, Case 6, 2020, para. 1), the normalization of a clearly sanist human rights violation is accompanied by the false construction of agency afforded to the subject who, through implied voluntarism, simply "gave up" their career. In Case 6, the implied deviance and dangerousness of madness, although redeemed through the presented self-inflicted sacrifice of a "promising teaching career", positions the mad subject as inherently pathological and particularly dangerous within the context of teaching children. "No one wanted me around children, even though everyone who knows me knows how much I care for them. I would jump in front of a bus for a child I've never met." (Siolkowsky, Case 6, 2020, para.1). The line, "No one wanted me around children" elicited a notable, visceral reaction in my body when I encountered it within the data and is a clear articulation of this disturbing discourse. Perhaps this is reflective of my own experience and identification as a mother, whereby my outrage with this particular discourse and the subsequent emotive response required reflexive journaling. CAMH's inclusion of the figure of speech, "I would jump in front of a bus" (Siolkowsky, Case 6, 2020, para.1) is also telling, as if the subject's protest to their perceived threat to children, or this discourse more generally, is framed as erratic, irrational and with suspected violence.

Similarly, Case 4 notes "her mental illness led her on a path that saw her give up [emphasis added] a career as a manager of recreational therapy in a nursing home" (Christina, 
Case 4, 2020, para.3). This discourse of madness as deviance and dangerousness is so deeply normalized (Wolframe, 2013), the implied lack of safety for vulnerable populations through the employment of individuals in Cases 4 and 6 is internalized through the lauded self-sacrifice of “giving up" one's career to prevent some type of inevitable harm. The responsibility to selfsurveil one's risk of violence, evident in the promotion of what is constructed as the ultimate, illusory "self-sacrifice" in neoliberal context, moves beyond the realm of lowered expectations and into the discourse of inevitable violence located within mad bodies, speaking to its confluence with carceral systems and unnecessary reference to incarceration in Case 5.

The CAMH psychiatrist indicates in Case 9, "what I worry about is what I saw in the first wave of patients at the emergency department after the pandemic started-the vulnerable people without housing or who are in traumatic situations or who are just leaving jail." (Zaheer, Case 9, 2020, para.2). According to Joseph (2019), in academic research and analysis, "the disproportionate use of incarceration, coercion, and the discourse of dangerousness to criminalize racialized and indigenous people in mental health systems proceeds relatively untouched" (Joseph, 2019, p.7). This reality, where the confluence of mental health and carceral systems is particularly ruthless in criminalizing racialized and Indigenous bodies, is also glaringly evident in this discourse. In Case 5 it is written, "then about a decade ago, he lost everything-his job, his house, his car-after an episode of first episode psychosis that landed him in jail for four months [emphasis added]. He was eventually diagnosed with bipolar schizoaffective disorder and transitioned out of the criminal justice system, where he once again turned to LOFT to get his life back together" (Pendenque, Case 5, 2020, para. 3). It is crucial to indicate that the profile images of the authors which accompany each testimonial have been included in analysis and are predominantly white bodies. Case 5, however, is a male-identified 
black body and the only testimonial which actively (and unnecessarily) references their incarceration multiple times, applying a causal relationship between "psychosis" and being "landed in jail", as well as implying violence and dangerousness. This contrasts with Case 4, who as a white mother also labelled with psychosis, indicates they simply weren't "right" (Christina, Case 4, 2020, para. 2) in their embodiment of this discourse. This reality will be analyzed further in the subsequent discussion chapter, with particular attention to the confluence of mental health and carceral systems and its effects on racialized and Indigenous bodies (Joseph, 2015), operating as a technology of colonialism and white supremacy, perpetuating the criminalization and dehumanization of racialized and Indigenous peoples (Joseph, 2019). The glaring, emphasized inclusion of incarceration in Case 5's description is perhaps the most poignant articulation in this data of the dehumanizing violence continually wielded upon black bodies at the confluence of psychiatric and carceral systems at this juncture.

\section{Discourse 5: We are all in this together: individualized collectivism}

There is contradiction in the idea of "individualized collectivism" as two seemingly antithetical concepts, however I feel it aptly describes the simultaneous promotion of alleged collectivism through particular phrases such as "we are all in this together" (Farrant, Case 2, 2020 para. 1) and "know that you are not alone" (Buchanan, Case 3, 2020, para.11) throughout the data, while maintaining the individualism required by its neoliberal context. This false collectivism, in direct contradiction to neoliberal values, is propagated in multiple examples within the data in reference to coping with COVID-19, without attention to the complexity of diverse individual experiences and structural realities. The quote "we are not all in the same boat but we are all in the same storm, and we are not alone in these unprecedented times" (Case 1, Elliot, para. 9) alludes to unified individual experiences or circumstances and maintains a 
collective, universal understanding of experiencing COVID-19. Using collective terminology to evade social responsibility, deny inequity and promote institutional marketing, in line with Sobande's (2020) analysis of corporate commodification of collectivist rhetoric during COVID19, CAMH is promoting this discourse, absolving discussion of any experienced disparities or inequity exasperated by this pandemic (or its relationship to the experience of distress), in support of the constructed good, mad subject as universally attainable. Contextualizing this discourse within CAMH's campaign offers indication of its apparent use to construct the mad subject in accordance to its propagated ideal, in confluence or conjunction with each of the other identified discourses. The universal mad subject is positioned within a psychocentric framework, in which the discourse "we are all in this together" implies a false universality of experience, understanding and construction of madness according to dominant, biomedical perspectives. All equal, all the same- with all the same implied potential and responsibility to attain status as the good, mad subject in accordance with neoliberal ideology. The inference is the necessary onus on the individual to achieve this imaginary status, in confluence with the discourse of responsibilization, through the presentation of collectivity as equity- in which if one does not meet the ideal outlined, they are constructed with inherent deficit.

Allusions to warfare, military and imperialism are also notable throughout the data, particularly in constructing this discourse. Case 2 indicates in multiple references to the "great wars" when discussing their methods of coping, "I have found myself watching a lot of movies and footage from the great wars and that collective mentality that we are all in this together" (Farrant, Case 2, 2020, para. 8). Case 2 was lauded for their "pioneering [emphasis added] advocacy work" when "named a CAMH difference maker" (Case 2, Farrant, 2020, para. 2) and this peculiar, eurocentric equation of collectivism to the "great wars" is devoid of any reference 
to collectivist origins, cultures or Indigenous perspectives, or the realities of cultural imperialism and co-option. Case 1 notes, “I wouldn't give a beginner's guide to coding to a soldier under fire. It's all about survival right now" (Elliot, Case 1, 2020, para. 9), in which the continued allusions to imperialism, normalized and valorized, are reflected in the eurocentric co-option and appropriation (Beresford \& Russo, 2016; Joseph, 2019) of collectivism and its application, engulfed by neoliberalism, in this discourse of individualized collectivism.

\section{Discourse 6: Lived experience and medicalization: psychiatry still knows best}

The propagation of psychiatric authority as a gatekeeping, epistemic hegemony within the psy-complex is explicit throughout the data, in its positioned dominance over the "epistemic trustworthiness" (Leblanc \& Kinsella, 2016, p.63) of lived experience. The epistemic violence in subjugating the knowledge of lived experience to psychiatry (Leblanc \& Kinsella, 2016) is evident throughout the data, as previously indicated in my notation of the insidious inclusion of a CAMH psychiatrist alongside lived experience narratives. The discourse in which psychiatry ultimately knows best or dominates is indicated in multiple references to institutional authority or the authority of psy-agents including psychiatrists and social workers, over the perspective of the authors throughout the testimonials. Case 8 indicates, "because I am a mental health advocate I have been getting a lot of requests for support. I never claim to be someone who can solve a serious and critical mental health problem, but I do have a lot of connections to doctors and therapists and other groups" (Hofer, Case 8, 2020, para. 5). The inferred "solvability" of "mental health problems" is placed within the expertise of the psy-complex. Referring to their "ghosts of mental illness", not only reminiscent of a transient, haunting imaginary, Case 1 also indicates "I deal with them by going back to the tools I learned during my time in crisis when all the social workers and doctors were helping me" (Case 1, Elliot, para. 5), re-entrenching the expertise and 
constructed "helpfulness" of psy professionals. The discursive presentation of madness through allusions to "ghosts" also implies deviance, fear and irrationality, while working to invalidate lived experience through this representation. As stated by Leblanc \& Kinsella (2016), "this form of objectification is particularly insidious as it occurs under the guise of welcoming or embracing Mad persons' knowledge (as informants), yet the accounts are sanitized in a way that makes Mad knowledge largely invisible" (p.67). Similarly, throughout this data lived experience knowledge is consistently buttressed by psy authority and subject to subtle delegitimization tactics.

In each case, the author is medicalized and constructed according to their specific psychiatric diagnosis which is always disclosed, in a similar manner as their definition according to profession. Case 1, for example indicates "she ended up at the CAMH emergency department, where she was diagnosed with Severe Panic Disorder caused (emphasis added) by untreated Generalized Anxiety Disorder" (para. 1). The reliance on psychiatric diagnosis in each of the testimonials speaks to Foucault's (in Ayo, 2012) concept of expert knowledge as critical to subjectivity formation. The medicalization of lived experience as well as the emphasis on treatment modalities offered by CAMH and affiliate organizations such as LOFT community services throughout the data also positions the authority of the psy-complex as superior. Case 5 notes that "as a young man, he found himself homeless on the streets of Toronto until LOFT Community Services helped him turn his life around [emphasis added]" (Pendenque, Case 5, 2020, para. 2). Case 5 continues:

"then about a decade ago, he lost everything-his job, his house, his car-after an episode of first episode psychosis that landed him in jail for four months. He was eventually diagnosed with bipolar schizoaffective disorder and transitioned out of the criminal justice system, where he once again turned to LOFT to get his life back together [emphasis added]" (Pendenque, Case 5, 2020, para. 3). 
The figures of speech such as "turn your life around" and "get your life back together" used within the data are reflective of a necessary "return" from deviance to prescribed normality or functionality as a neoliberal subject. The reliance upon psy-experts and organizations to facilitate this return from deviance implies necessary surveillance, while the use of the phrase "once again" is also suspect, as it implies a negative connotation to recurring engagements with psy institutions. I can imagine the intonation of the phrase and its exasperation, in which the inferred negativity associated with the phrase "once again" also speaks to the discourse of responsibilization, framing what is constructed as reliance upon psy institutions as antithetical to the neoliberal subject or ideal CAMH family member. 


\section{CHAPTER 5. DISCUSSION}

This chapter will analyze the relevance of the discourses identified from CAMH's Coping with COVID-19 campaign. Coping with COVID-19 can be classified as an anti-stigma awareness campaign in its apparent attempts to normalize and destigmatize "mental illness" through its construction of the good, mad subject at this juncture of COVID-19. The discourses I identified are "responsibilization", "successful recovery is a return to work", "mental health is health", "madness as deviance, violence and dangerousness", "we are all in this together", and "lived experience and medicalization". The data reproduces the themes and discourses identified within my literature review and particularly appeals to responsibilization and the construction of the neoliberal self (Rimke, 2016). The prescribed construction of the good, neoliberal mad subject through technologies of self are evident in the identified discourses. The construction of the ideal mad subject or CAMH family member through these discourses is embedded within a violent trajectory of colonialism and eugenic rationale, operationalizing technologies of white supremacy and requiring intense interrogation.

As stated by Foucault (1990):

We must make allowances for the complex and unstable processes whereby discourse can be both an instrument and an effect of power, but also a hindrance, a stumbling block, a point of resistance and a starting point for an opposing strategy. Discourse transmits and produces power; it reinforces it but also undermines it and exposes it, renders it fragile and makes it possible to thwart it [emphasis added] (p.101).

The relevance of discourse analysis to critical social research and its potential to expose insidious power and dominance has become increasingly apparent to me throughout this process. According to Joseph (2015), "first-person perspectives are also revealing of the dominant cultural norms and political circumstances of the time" (p.1027) and I question the ways these narratives are reflective of increasing austerity measures pushed in our political context as well 
as social realities and increasing precarity in COVID-19. Fuchs (2020) indicates "neoliberal crisis action tolerates an increase of poverty, misery, debt, precarity, homelessness, unemployment etc. in order to reorganise society in the interest of capital in a state of emergency" (p.382) and this necessarily informs our context. The relevance of lived experience narratives, or those presented as such, are their discursively rich sites of analysis. From the outset of this campaign each individual is described as a "member of the CAMH extended familyspecifically people with lived experience of mental illness who have made a commitment to mental health advocacy" (O’Malley, 2020, para.1). Mental health advocacy in this context is constructed according to psychocentric perspectives, is conflated with efforts aimed to reduce stigma and measured by an individual's level of engagement with or promotion of CAMH psychiatric services. Advocacy is framed as promotion of the CAMH agenda. The relevance of this research is its potential to reveal the contemporary construction of madness within the discursive production of a dominant institution as well as the technologies which support the collective consciousness of white supremacy (van Dijk, 2012) through the analysis of discourses. According to Joseph (2013), technologies of violence "owe their inheritance to the orientalising discursive practices and disciplinary hegemony developed during colonization that when ignored, reproduce the dehumanizing outcomes upon which they were built" (p.273). These colonial technologies of violence insidiously (re)produce the same eugenic hierarchies their legacy cultivates, operationalizing domination and facilitating contemporary dehumanization practices according to a colonial, white supremacist logic.

\section{Context: History understood in its contemporary manifest}

"Confluence demands a historical consideration, an appreciation of the temporal" (Joseph, 2015, p.17) requiring an analysis which situates this campaign within the legacy of 
$\mathrm{CAMH}$ as an institution and its inextricable relationship to eugenics, colonialism and white supremacy. Eugenic rationale has operationalized a wealth of violent policies, laws and practices and is embedded within the Canadian health care and psychiatric systems (Joseph, 2019). As Joseph (2019) indicates, "western psychiatric biomedicine, immigration regulation, and criminal justice systems must be considered within their historical confluence for their interdependent use and advancement of racial and eugenic ideas for projects of colonization and nation building" (p.170). Necessarily contextualizing these "processes and technologies of dehumanization" (Joseph, 2019, p.170) evident in discourses throughout the data requires a brief examination of the hegemonic institution which actively (re)produces them.

Although impossible to provide a comprehensive overview of CAMH's history as an institution in this paper, I must at least consider the legacy of present day CAMH grounds, whose brick and mortar institution is the architectural site of a deep-seated history of psychiatric incarceration, eugenics and colonialism in our local context of Toronto. The present grounds and site of a "modern health facility" has been the site of psychiatric institutions for over 160 years (CAMH, 2020). What was originally termed the Ontario Provincial Lunatic Asylum was "renamed Asylum for the Insane in 1871, Hospital for the Insane in 1905, and simply Ontario Hospital, Toronto as of 1919. In 1996, it became Queen Street Mental Health Centre and finally, Centre for Addiction and Mental Health (CAMH) in 1998" (CAMH, 2020, para. 2). According to CAMH (2020), "the changing view of mental health can be seen in the institution's various name changes over the years" (para. 2). Following the 1998 merger:

the Health Services Restructuring Committee, an independent agency appointed by the provincial government to redesign the Ontario health system, tasked CAMH to address four key challenges: quality of care, access to care, fragmentation of services and stigma - a mandate CAMH continues to grow to this day (CAMH, 2020, para.5). 
According to Lucy Costa of the CAMH Empowerment Council, "it's important we remember our history, because it's an opportunity to learn from our past. Patients historically have had other people speak for them. It really becomes important to be sensitive to, and mindful of...the patient voice" (CAMH, 2020, para 7). CAMH alleges patient voice is centered in its campaigns which include its promotion of "lived experience", taking great effort to "mind the patient voice" without any reference to its historical trajectory, history of violence or colonial context.

The legacy of patient heritage wall construction at CAMH's Queen street site as discussed by Reaume (2010) represents the historic exploitation of unpaid patient labour as 'moral therapy' and the minimal acknowledgement or mainstream examination of this form of historic indentured servitude, or as Joseph (2013) argues, slavery. CAMH (2020) claims "over the decades, some patients inscribed words, phrases and X's into the wall, standing to this day as poignant testimony to their mental suffering - and the attitudes of the day toward them" (para.6). The co-option of this history by CAMH to support their anti-stigma narrative and place emphasis upon "mental suffering" makes no reference to the current carceral experience of many patients, the violent practices justified by a eugenic rationale or the inhumanity endured throughout the site's history. This historical appeal to "moral therapy" is also reminiscent in the discourse "successful recovery is a return to work", in which the manifestation of this exploitative practice of indentured servitude (whether to the community or the capitalist system) is identified and reflected within contemporary discourse.

CAMH's foundational relationship to eugenics and the preservation of what Voronka (2008) terms "Canadian mythology" (p.54) or white narrative through the Queen St. site in particular, is relevant to this work as the data taken from this CAMH campaign emerges directly 
from this particular historical trajectory, entirely a product of its legacy and contemporary manifest. The data is suspended within a legacy of eugenics, colonialism and white supremacy, as well as the specific history of the Queen St. site and psychiatric practice in local context. There is a foundational relationship between CAMH as an institution and psychiatry more generally with the eugenics movement. Contemporary anti-stigma campaigns at CAMH are preceded by the projects of revitalization/redevelopment of its architectural asylum space, which Voronka (2008) describes as its historic attempts to destigmatize the space to "contribute to the ongoing revitalization of the surrounding neighbourhood and address decades of stigma around mental health and addictions" (Urban Strategies, 2002, in Voronka, 2008, p.58) As Voronka (2008) contends, CAMH, including "the site and its built spaces have contributed to metanarratives of Canada as a white, middle-class nation that needs to protect its citizens from a mad degenerate underclass" (p.48). This is evident in the data analyzed and identified discourses, particularly madness as deviance and violence.

According to Voronka (2009) CAMH's Queen St. site historically operated as a "site of carceral containment of mad bodies" (p.46) and simultaneously functioned as spatial containment to historically produce an idealized white nation and segregate the "degenerate threat of madness" (p.47) through geographies of exclusion. Accordingly, "madness was framed through an understanding of degenerative illness as hereditary deviance, which lurked in the body and was passed down through tainted genes" (Voronka, 2008, p.48) and the spatial confinement, according to Voronka (2008), operated as a tool of the colonial project "to create and solidify a history of whiteness in Canada" (p.48). Joseph (2013) refers to Roman et al. who argue "colonial western psychiatry had been described as a necessary vehicle used to advance colonial nation building and the very definition of 'civil' society" (p.285), in line with Mills \& 
LeFrançois (2018) who indicate "that conceptions of normal and pathological behaviour and psychology were made possible through the colonial binary of the "normal" West and the pathological Rest" (p.513) in which the psy-disciplines "have been constituted through colonialism and so are always already a colonial practice" (p.520). Joseph (2015) similarly addresses the reliance on colonial technologies to support the colonial project, embedded within criminal justice and mental health systems to operate as mechanisms of social control. Joseph (2019) writes:

The processes and technologies of dehumanization have always been necessary for colonial and imperial projects. For exploitation, slavery, indenture, the colonization of lands, the upheaval of governments, and the imposition of religion to occur, a group had to be differentiated, subordinated into a general type, and seen through a lens of difference as an inferior group in need of Western civility, democracy, psychiatry, capitalism, and Christianity, and deemed worthy of violence and reasoned out of humanity (Joseph, 2019, p.170).

The historic "threat of incarceration to anyone daring to deviate outside of the realm of reason" (Voronka, 2008, p.49) in which the production of the sane subject is in part established through one's relationship to and positioning as either inside or outside psychiatric institutional walls. This "psychiatric architecture" (Voronka, 2008) could be analogous to a contemporary form of online or virtual psychiatric architecture and the production of a new, virtual asylum. I'm curious how digital media campaigns such as these, which similarly operate to produce the mad or sane subject according to prescribed inclusion and exclusion criteria, may be similarly established through one's relationship to and identification with these norms and discourses, communicated online and operating as virtual, institutional walls. Given our temporal context as living in COVID-19 with its vast increase in our engagement with the virtual world, this production of the sane subject through engagement with virtual psychiatric architecture may be inevitable. 


\section{Discourse of dangerousness and violence as colonial technology}

According to Joseph (2015):

Racial oppression is not sustained by madness; rather, madness and savagery were/are co-constituted through a confluence of ideas that rationalized forms of violence on bodies of difference deemed worthy of harm or exclusion. They serve together to shore up notions of civility and incivility; they do not now nor have they ever existed without one another (p.1037).

Joseph (2019) articulates the concrete effects of internalized discourses of violence and dangerousness in the construction of madness, permitting fears of perceived public harm and criminalization resulting in increased surveillance, involuntary confinement, forced hospitalization and imprisonment of individuals allegedly "prone to criminality" (p.179). The discourse of dangerousness and violence is used to criminalize racialized and Indigenous bodies (Joseph, 2019) and activate dehumanization tactics at the confluence of psychiatric and carceral systems. The confluence of systems operating upon Black bodies as evident in Case 5 must be contextualized within the legacy of colonial violence on racialized bodies and its relationship to the construction of madness, made evident here in the explicit construction of their embodiment/lack of embodiment of CAMH's ideal mad subject.

Repeatedly constructed as "fortunate" and dependent on external programs and resources to "get his life back together" (Pendenque, Case 5, 2020, para. 3), Case 5 is presented as requiring surveillance of their distress and necessary institutional intervention on multiple occasions, in contrast with the implied agency afforded to other Cases such as Case 8, which "says she can now predict fairly accurately when her mental health is starting to deteriorate again and it is time for another maintenance treatment of rTMS, usually about 7 or 8 months later" (Hofer, Case 8, para.2) while referring to the "tools" they possess to "deal with" (Case 1, Elliot, para. 5) their distress. It is by no coincidence that autonomy is presented to the white subjects, in 
which white supremacist racial hierarchies are evident in their implied autonomy versus prescribed reliance on external services to manage their "illness". The infantilization of subjects (Mills \& LeFrançois, 2018) and parentification of agencies in Case 5 is constructed as necessary intervention to keep racialized mad bodies out of carceral systems. In Case 5 (Pendenque, Case 5, 2020) it says "He feels fortunate these days. Fortunate to have a job and stable housing. Fortunate to be alive at all [emphasis added]" (para.4). The repeated use of the term fortunate is suspect and implies favourable luck to one's circumstances versus active agency and control, while the reference to death, arguably framed as inevitable without intervention or "life saving supports" (para. 4), could either be analyzed as reflective of discourses related specifically to the diagnosis of bipolar schizoaffective disorder or the confluence of discourses related to madness generally.

According to Joseph (2015) we rely on:

particular colonial tropes for the constructing of identities of dehumanized difference and the reliance on racial and eugenic rationale to provide the authority for and legitimization of violence, the continuation of the production of ordered subjects, a reliance on old colonial machinery, and the (re)positioning of authority and legitimacy through violence and difference (p.35).

The active, eugenic production of difference to structure the prescribed norm or ideal subject requires the simultaneous prescription of "other" forged through violent colonial technologies (Joseph, 2015) and the subjugation of Indigenous knowledges to bolster eurocentric domination. The discourse of dangerousness applied to racialized and Indigenous Peoples, particularly within a psychiatric context, is an active technology of the colonial nation building project (Joseph, 2019) used to operationalize white supremacy. I feel this eugenic production is particularly evident in its comparatively explicit presence within Case 5, the only male-identified 
black subject who is constructed in relation to their incarceration, their relationship to the "right life-saving mental health supports" and repeatedly termed "fortunate".

I am wary of my analysis. I am cautious of the way my white lens is simply (re)producing this discourse of madness as deviance in its violent application upon racialized bodies, when I attempt to call it out and I question whether I am simply (re)constructing a discourse from my own internalized racism. I feel that tension and I recognize the violence, yet I may simply be applying my own internalized white supremacy to the data. My own leaning into eurocentrism, suspension within it and existence as a product of it is entirely suspect. I am reminded of Rovet's (2017) caution in which we as students are simply writing our papers, working within a colonial institution to "earn" a degree within a colonial context entirely constituted by eurocentrism and white supremacy. This entire process is indictable and I am not lost to that reality.

\section{Coopting collectivism}

There is active, continued genocide and contemporary subjugation of Indigenous Peoples and knowledges, operating to erase Indigenous existence in an attempt to permit land theft or colonial "ownership" (Joseph, 2014) in our local context and across the globe. The colonial appropriation of Indigenous spirituality as described by Joseph (2014) and its inference that Indigenous Peoples do not exist as a sovereign nation can be applied to the cooption of collectivism to serve colonial interests evident in the identified discourse "we are all in this together" within the data.

CAMH (2020) states on their website:

CAMH is committed to reconciliation. We will honour the land through programs and places that reflect and respect its heritage. We will embrace the healing traditions of the Ancestors, and weave them into our caring practices. We will create new relationships and partnerships with First Nations, Inuit and Métis - share the land and protect it for future generations. 
Their antithetical sentiment to their participation in Indigenous erasure and complete absence of Indigenous-identified voices or perspectives in this data are beyond epistemic injustice. The cooption of collectivism and appropriation of spirituality in Case 4 for example, who in discussion of their art endeavours indicates "I've been told that dragonflies hold a lot of meaning for some people, a spiritual thing like feathers that symbolizes a loved one nearby" (Siolkowsky, Case 4, para. 7) as well as the continued use of the term "spiritual" are suspect. Feathers are often used in many Indigenous traditions including Anishinabek symbolism (Gray 2017), which is relevant considering Toronto's location on traditional Anishinaabe land. The lack of attention to white cooption of this type of symbolism is not surprising. "I think I needed this on a spiritual level. I needed this slowdown to really reflect, practice my deep breathing and meditation and thinking about what is really important" (Case 3, Buchanan, para. 7). The reference to "spirituality" also occurs alongside multiple references and allusions to Christianity through visuals in Case 8 and Case 5. As Mills and LeFrançois (2018) contend, "psychiatrization is thus deployed in order to divert attention away from the violence exerted upon colonized peoples" (p.513). The diversion of attention away from the violent realities of colonization are used to permit land theft (Joseph, 2014), support the colonial agenda, eurocentrism and white supremacy (Mills \& LeFrançois, 2018).

According to Joseph (2019) and applicable to this analysis:

is the ethical obligation to resist forms of white supremacy that would position lived experience with psy disciplines as more visible, more important, or more noteworthy than the intergenerational forms of suffering, distress, and violence as they are lived by racialized and indigenous people today (p.16).

In the context of this data, CAMH's campaign and in anti-stigma campaigns more generally, the absence of acknowledgement or analysis of the intergenerational forms of violence experienced by racialized and Indigenous peoples is reflective of white supremacy in the focused 
construction of the good mad subject in line with Joseph's (2019) analysis of lived experience discourses. According to Boyd \& Kerr (2015), "institutionally based claim makers define the nature of the "mental health crisis" and they also offer solutions to this problem that correspond with their institutional priorities and concerns (Best, 1995), reinforcing technologies of social control" (p. 419). This analysis could be extended to CAMH and major institutional players in the production of our realities, particularly within the context of distress and mad identity, to reflect their own priorities and prescribed "solutions" to constructed problems. This argument is often applied to debates around 'Big pharma's relationship to madness (Rimke, 2016) which may be applicable here, however in this particular case it is also reflective of the dominant white supremacist project, in which institutional priorities are reflective of simply maintaining the status quo.

\section{Implications and recommendations}

Limitations of this research as a modified critical discourse analysis are not limited to the limitations of my lens as a single researcher, or the lack of comprehensive examination of data in the interest of space and time. As a pilot project, this modified CDA lacks adequate context as well as the intense depth and far reaching analysis required for a traditional CDA. This particular data set was limited in text and I often compared the minimal text to other modified CDAs conducted in this program which were much more extensive, particularly in the use of articles or public documents. The nature of my research was highly specific to one digital media campaign and institution, perhaps adequate for the parameters of this assignment but nothing further. I must acknowledge there are infinite potential frameworks and analyses to draw from and this work is therefore missing many potential points of inquiry, in which a differing perspective analyzing this discursively rich content may yield radical results. 


\section{Resisting positivism}

The many forms of violence evident in this campaign, not limited to epistemic violence and the subjugation of Indigenous knowledges or non-eurocentric perspectives and what Žižek terms (in Joseph, 2019) "objective violence" or the normalized status quo, necessitate discursive extrapolation and critical interrogation. Foucault framed critiques to the status quo as resistance in itself, however there is more we can do. Carlson (2016) indicates "eurocentric scholarly hegemony venerates detachment and abstraction" (p. 501) which from my perspective is impossible in research. Incorporating a visceral dimension as methodology in critical discourse analysis may prove useful as a means to resist positivist, eurocentric influence in this type of social research. Ellingson (2006) discusses the incorporation of "embodied writing" or a researcher's sensory experience in qualitative health research using examples such as autoethnographic writing and interrogating bodily connections to the research. The application of these ideas to critical discourse analysis, through a monitoring of visceral reactions when engaging with the data, is something novel I attempted in this process and provided useful points of inquiry. I kept a notation each time I experienced a significant visceral reaction, then analyzed it reflexively and used it as a point of inquiry.

I feel that taking a largely eurocentric methodology which is positioned as credible within academic discourse and radically engaging with it in a (re)structured way, informed by principles of decolonization to circumvent the reality in which positivism dominates credibility and harness its legitimacy to achieve social change could be considered an act of methodological resistance. The potential to shift critical discourse analysis to incorporate an increasingly full bodied (re)engagement with data as praxis and establish a radical, new form of reflexivity in CDA with emphasis on visceral interpretations, could prove beneficial in not only centering non- 
dominant knowledges and resisting positivist influence in qualitative research, but re-inscribing the inevitable, subjective realities of CDA which are inherent to the methodology, as knowledge in itself. In this way we may harness credibility and use it to radically alter our engagement with methodology to support decolonizing praxis and challenge the western knowledge regime. This type of engagement also requires radical critical reflexivity, but the potential insight it may provide is significant. As Joseph (2015) cautions, "we can miss the violence infused in the very professions, disciplines, and practices we wield to address issues of social justice" (p.1028) and it is difficult to deny the reality in which CDA as a methodology also functions as/is a product of eurocentrism and in turn supports white supremacy. 


\section{CHAPTER 6: CONCLUSION}

Bell hooks (1989) stated over 30 years ago:

when liberal whites fail to understand how they can and/or do embody white supremacist values and beliefs, even though they may not embrace racism as prejudice or domination, . . they cannot recognize the ways their actions support and affirm the very structure of racist domination and oppression that they wish to see eradicated (p.113).

There is infinite tension in these realities, complexities which indict us all and I truly question any claim to critical work. This isn't all hopeless and lost; if anything, there is a unification of voices when we proceed beyond identity politics to examine the greater project which is underlying, manifest so delicately throughout or bodies and lives as we dare to acknowledge it. White supremacy is the project which directs our experiences and feelings of violence and marginalization, that these systems work in confluence to maintain it and the examination of these mechanisms is a practical means of calling up disruption. As a white body, I entirely benefit from a white supremacist system, yet I simultaneously experience the violence of technologies and eugenic rationale which are harnessed to maintain it. This seeming contradiction represents the vastly complex individual embodiment of realities we all uniquely experience and the fluidity of their confluence suspended within the infinite trajectory of colonialism. There's a sense of solidarity in this theory.

I consider the usefulness of bringing forth confluence as a theoretical framework in future social work education. It offers space to radically engage with our own implications, indicts us all and encourages engagement with complicity in a manner often avoided among students. In their discussion of critical whiteness studies as a theoretical framework, Applebaum (2016) 
mentions the relational dimension of white privilege as deeply embedded throughout social structures and processes, existing in confluence with infinite processes, in line with Joseph's (2015) theory. They indicate

that a preoccupation with being "good" can block challenges to systemic oppression... whites "must interrogate the very ways of being good . .., for the moral framing that gives whites credit for being anti-racist is parasitic on the racism that it is meant to challenge (Applebaum, 2016, para. 72).

In our current context it seems many white bodies, particularly social workers and social justice seekers may be preoccupied with this "moral framing" and credit-seeking for claims to anti-racism. This requires intense interrogation and I myself have asked, why am I doing the things I do and for who? Are we interrogating what we consider the "ways of being good" at all, especially without calling attention to insidious technologies and discourses which operationalize white supremacy? "The vigilance that is necessary for social justice education, and especially for teaching white students about their complicity in racism, therefore, must be a vigilance about whites' own goodness, not only a vigilance about their negative beliefs about "others." (Applebaum, 2016, para. 76-77).

CAMH as an institution is heavily drawn from as a "change maker" (CAMH, 2020), with their research used to influence policy. $\mathrm{CAMH}$ "is committed to driving social change by communicating evidence-based public policy to stakeholders and policymakers. Our policy positions are developed in collaboration with a range of experts including scientists, clinicians, educators and people with lived experience" (CAMH, 2020, para.1). Their influence transcends their discursive potential and indoctrination of the masses in their direct political associations which ultimately permeate all areas of social policy. 
When institutions begin to stake claim in false narratives and feign compassion and concern for a superficial rundown of the deep legacy of violence inflicted upon racialized bodies, Black bodies, Indigenous bodies, queer bodies, trans bodies and mad bodies, it is a co-option of a social movement of resistance under a false presentation of solidarity. As Black Lives Matter becomes a commonly uttered political position from white mouths and hegemonic institutions who exist within a complex legacy of (neo) colonialism and do nothing to expose their mechanization and embodiment of the violence Black Lives Matter seeks to resist and overthrow, its more than mere hypocrisy- it is active colonial violence in service of white supremacy. It is no coincidence that CAMH centres the voices of its choice to serve its interest as a dominating institution and our inquiry should be tirelessly relentless.

As Joseph (2015) so aptly contends, "we are all complicit in the formation and (re)production" of systems of domination (p.24). There is no expertise (Joseph, 2015) and as social workers we are afforded "exceptional and non-transparent" discretionary powers" when designated as "mental health professionals" (Joseph, 2019, p.172). Many of us are not lost to this power, but I have learned to constantly remind myself of its tensions and our propensity to embody and inflict violence in all research and practice. I have learned the confluence of racism, sanism and the discourses embedded in this seemingly harmless, do-good virtual media campaign are internalized by the very social workers who espouse social justice rhetoric yet engage in its reproduction. We claim to be allies, accomplices and the like, we march and rally and engage in the activism we claim to do, yet we rely on these assumed realities which inform our life and work and we are not divorced from it. We claim allyship yet engage in sanist praxis, which is in inextricable confluence with racism. We're encouraged to "confront" and "disrupt" racism, yet the operation of technologies which serve the project of white supremacy often 
remain undetected in infiltrative discursive mechanisms such as the ones extracted in this research.

These discursive mechanisms operating through virtual media are only ramping up in their prevalence and influence during COVID-19 and what will eventually become a postCOVID world. I would encourage more inquiry in this area of research to examine what, exactly we are (re)producing, consider who it is serving and for what purpose. In September 2020 CAMH launched what they brand Not Today, a similar virtual media campaign described as "the biggest campaign in its history, to prevent suicide today, tomorrow and every day after that" (para 1.). Despite their obvious increased inclusion of racialized bodies in their lived experience testimonials for the Not Today campaign, the discourses I identified persist, including the discourse of dangerousness. I implore someone to look at it and critically analyze it. Call it out. Publish it. Who knows, maybe I will.

As the aforementioned scholars have taught me, stay implicated in all you critique. 


\section{REFERENCES}

Ahmedani B. K. (2011). Mental health stigma: society, individuals, and the profession. Journal of social work values and ethics, 8(2), 1-16.

Amoussou, A. \& Allagbe, A. (2018). Principles, theories and approaches to critical discourse analysis. International Journal on Studies in English Language and Literature, 6(1), 1118. https://doi.org/10.20431/2347-3134.0601002

Applebaum, B. (2016). Critical whiteness studies. Oxford Research Encyclopedia of Education, https://doi.org/10.1093/acrefore/9780190264093.013.5

Ayo, N. (2012). Understanding health promotion in a neoliberal climate and the making of health conscious citizens. Critical Public Health, 22(1), 99-105. https://doi.org/10.1080/09581596.2010.52069

Bacchi, C., \& Bonham, J. (2014). Reclaiming discursive practices as an analytic focus: Political implications. Foucault Studies, 179-192. https://doi.org/10.22439/fs.v0i17.4298

Baklien, B., \& Bongaardt, R. (2014). The quest for choice and the need for relational care in mental health work. Medicine, Health Care and Philosophy, 17(4), 625-632. https://doi.org/10.1007/s11019-014-9563-z

Bell, C. (2010). Is disability studies actually white disability studies? In L. J. Davis (Ed.), The Disability Studies Reader (3rd ed., pp. 374-382). New York, NY: Routledge.

Beresford, P. (2019). 'Mad', Mad studies and advancing inclusive resistance. Disability \& Society, 1-6. https://doi.org/10.1080/09687599.2019.1692168 
Berlim, M. T., Fleck, M. P. A., \& Shorter, E. (2003). Notes on antipsychiatry. European Archives of Psychiatry and Clinical Neuroscience, 253(2), 61-67. https://doi.org/10.1007/s00406-003-0407-8

Biringer, E., Davidson, L., Sundfør, B., Ruud, T., \& Borg, M. (2016). Service users' expectations of treatment and support at the Community Mental Health Centre in their recovery. Scandinavian Journal of Caring Sciences, 31(3), 505-513. https://doi.org/10.1111/scs.12364

Booth, RG., Allen, BN., Bray Jenkyn, KM., Li, L. \& Shariff, SZ. (2018). Youth mental health services utilization rates after a large-scale social media campaign: population-based interrupted time-series analysis. JMIR Mental Health, 5(2), 1-15.

Boyd, J., \& Kerr, T. (2016). Policing 'Vancouver's mental health crisis': a critical discourse analysis. Critical Public Health, 26(4), 418-433. https://doi.org/10.1080/09581596.2015.1007923

Briscoe, F. M., \& Khalifa, M. A. (2013). 'That racism thing': a critical race discourse analysis of a conflict over the proposed closure of a black high school. Race Ethnicity and Education, 18(6), 739-763. https://doi.org/10.1080/13613324.2013.792798

Buchanan, S. (2020). Learn to be kind to yourself. https://www.camh.ca/en/health-info/mentalhealth-and-covid-19/coping-with-covid-19/learn-to-be-kind-to-yourself 
Burstow, B. (2015). Psychiatry and the business of madness: an ethical and epistemological accounting. New York, NY: Palgrave Macmillan.

Carlson, E. (2016). Anti-colonial methodologies and practices for settle colonial studies. Settler Colonial Studies, 7 (4), 496-517. https://doi.org/10.1080/2201473x.2016.1241213

Carter, S. M., \& Little, M. (2007). Justifying knowledge, justifying method, taking action: epistemologies, methodologies, and methods in qualitative research. Qualitative Health Research, 17(10), 1316-1328. https://doi.org/10.1177/1049732307306927

Centre for Addiction and Mental Health (n.d.). About CAMH. Retrieved from https://www.camh.ca/en/driving-change/about-camh

Centre for Addiction and Mental Health (n.d.) Addressing stigma. Retrieved from https://www.camh.ca/en/driving-change/addressing-stigma

Centre for Addiction and Mental Health (2020). History of Queen street site. Retrieved from https://www.camh.ca/en/driving-change/building-the-mental-health-facility-of-thefuture/history-of-queen-street-site.

Centre for Addiction and Mental Health (2018, May 7). Mental health is health. Retrieved from https://www.camh.ca/en/camh-news-and-stories/mental-health-is-healthrelease\#: : text=and\%20every\%20year.,What $\% 20$ this $\% 20$ campaign $\% 20$ is $\% 20$ saying $\% 20$ is $\% 20$ that $\% 20$ all $\% 20$ Canadians $\% 20$ ne ed,therapy $\% 20$ and $\% 20$ magnetic $\% 20$ brain $\% 20$ stimulation.

Centre for Addiction and Mental Health (2020). Raising the profile of mental health across Canada. Retrieved from https://www.camh.ca/en/camh-news-and-stories/raising-theprofile-of-mental-health-across-canada 
Centre for Addiction and Mental Health (2020). Influencing public policy. Retrieved from https://www.camh.ca/en/driving-change/influencing-public-policy

Centre for Addiction and Mental Health (2020). Driving change: mental health is health. Retrieved from https://www.camh.ca/en/driving-change/mental-health-is-health

Chapman, C., Azevedo, J., Ballen, R., \& Poole, J. (2016). A kind of collective freezing-out: how helping professionals' regulatory bodies create "incompetence" and increase distress. In Bonnie Burstow (Eds.) Psychiatry Interrogated, pp. 41-61. https://doi.org/10.1007/978$\underline{3-319-41174-3 \quad 3}$

Charmaz, K. (2016). The power of constructivist grounded theory for critical inquiry. Qualitative Inquiry, 23(1), 34-45. https://doi.org/10.1177/1077800416657105

Cheng, J., Benassi, P., de Oliveira, C., Zaheer, J., Collins, M., \& Kurdyak, P. (2016). Impact of a mass media mental health campaign on psychiatric emergency department visits. Canadian Journal of Public Health, 107(3), e303-e311. https://doi.org/10.17269/cjph.107.5265

Christina, A. (2020). Making do with what you have. https://www.camh.ca/en/healthinfo/mental-health-and-covid-19/coping-with-covid-19/making-do-with-what-you-have

Collins, R. L., Wong, E. C., Breslau, J., Burnam, M. A., Cefalu, M., \& Roth, E. (2019). Social marketing of mental health treatment: California's mental illness stigma reduction campaign. American Journal of Public Health, 109(S3), S228-S235.

https://doi.org/10.2105/ajph.2019.305129 
Corrigan, P, Druss, B., Perlick, D. (2014) The impact of mental illness stigma on seeking and participating in mental health care. Psychological Science in the Public Interest, 15(2), $37-70$.

Crowe, A., Averett, A. (2015). Attitudes of mental health professionals toward mental illness: a deeper understanding. Journal of Mental Health Counseling, 37 (1), 47-62.

DeFehr, J. N. (2016). Inventing mental health first aid: The problem of psychocentrism. Studies in Social Justice, 10(1), 18-35. https://doi.org/10.26522/ssj.v10i1.1326

Dej, E. (2016). Psychocentrism and homelessness: The pathologization/responsibilization paradox. Studies in Social Justice, 10(1), 117-135. https://doi.org/10.26522/ssj.v10i1.1349

Denzin, N. K. (2017). Critical qualitative inquiry, Qualitative Inquiry, 23 (1), 8-16.

Dyson, H., \& Gorvin, L. (2017). How is a label of Borderline Personality Disorder constructed on twitter: a critical discourse analysis. Issues in Mental Health Nursing, 38(10), 780790. https://doi.org/10.1080/01612840.2017.1354105

Eiroa-Orosa, F. J., \& Lomascolo, M. (2018). Training mental health activists increases the wellbeing of participants with high baseline levels of self-stigma: Results of the Obertament training evaluation. American Journal of Orthopsychiatry, 88(6), 617-625. https://doi.org/10.1037/ort0000376 
Ellingson, L. L. (2006). Embodied knowledge: writing researchers' bodies into qualitative health research. Qualitative Health Research, 16(2), 298-310. https://doi.org/10.1177/1049732305281944

Elliot, A. (2020). The ghosts of mental illness return. https://www.camh.ca/en/healthinfo/mental-health-and-covid-19/coping-with-covid-19/the-ghosts-of-mental-illness-return

Evans-Lacko, S., Kohrt, B., Henderson, C., \& Thornicroft, G. (2017). Public anti-stigma programmes might improve help-seeking. British Journal of Psychiatry, 211(3), 182. https://doi.org/10.1192/bjp.211.3.182

Fairclough, N. (1992). Discourse and text: linguistic and intertextual analysis within discourse analysis. Discourse \& Society, 3(2), 193-217. https://doi.org/10.1177/0957926592003002004

Fairclough N. (2010) Critical discourse analysis. The critical study of language. New York, NY: Routeledge.

Farrant, M. (2020). We are all in this together. https://www.camh.ca/en/health-info/mentalhealth-and-covid-19/coping-with-covid-19/we-are-all-in-this-together

Foucault, M. (1967) Madness and civilisation. London: Tavistock.

Fuchs, C. (2020). Everyday life and everyday communication in coronavirus capitalism. TripleC: Communication, Capitalism \& Critique. Open Access Journal for a Global Sustainable Information Society, 18(1), 375-398. https://doi.org/10.31269/triplec.v18i1.1167 
Fylkesnes, S. (2018). Whiteness in teacher education research discourses: A review of the use and meaning making of the term cultural diversity. Teaching and Teacher Education, 71, 24-33. https://doi.org/10.1016/j.tate.2017.12.005

George, P. \& George J. (2013). Interrogating the neoliberal governmentality of the old age security act: the case of sponsored immigrant seniors. Canadian Social Work Review, 31 $(1), 65-81$.

Gorman, R. (2017). Quagmires of affect: madness, labor, whiteness, and ideological disavowal. American Quarterly, 69(2), 309-313. https://doi.org/10.1353/aq.2017.0025

Graham, R., \& Smith, S. (2016). The content of our \#characters. Sociology of Race and Ethnicity, 2(4), 433-449. https://doi.org/10.1177/2332649216639067

Grant, A. (2013). Troubling 'lived experience': a post-structural critique of mental health nursing qualitative research assumptions. Journal of Psychiatric and Mental Health Nursing, 21(6), 544-549. https://doi.org/10.1111/jpm.12113

Gray, M. (2017) Beads: symbols of Indigenous cultural resilience and value. Unpublished Master's Thesis. Toronto: University of Toronto, Department of Anthropology.

Greenberg, N., Docherty, M., Gnanapragasam, S., \& Wessely, S. (2020). Managing mental health challenges faced by healthcare workers during covid-19 pandemic. $B M J, \mathrm{~m} 1211$. https://doi.org/10.1136/bmj.m1211

Guterres, J. (2018). Who is enough? An investigation into experiences of exclusion within critical mental health and mad organizing. Unpublished Major Research Paper. Toronto: Ryerson University, School of Social Work. 
Evans-Lacko, S., Kohrt, B., Henderson, C., \& Thornicroft, G. (2017). Public anti-stigma programmes might improve help-seeking. British Journal of Psychiatry, 211(3), 182. https://doi.org/10.1192/bjp.211.3.182

Hansen, J. (2016). Meaning systems and mental health culture: critical perspectives on contemporary counselling and psychotherapy. London, U.K. Lexington Books.

Hanisch, S. E., Twomey, C. D., Szeto, A. C. H., Birner, U. W., Nowak, D., \& Sabariego, C. (2016). The effectiveness of interventions targeting the stigma of mental illness at the workplace: a systematic review. BMC Psychiatry, 16(1), 1-11. https://doi.org/10.1186/s12888-015-0706-4

Henderson, C., Robinson, E., Evans-Lacko, S., \& Thornicroft, G. (2017a). Relationships between anti-stigma programme awareness, disclosure comfort and intended helpseeking regarding a mental health problem. British Journal of Psychiatry, 211(5), 316322. https://doi.org/10.1192/bjp.bp.116.195867

Hofer, S. (2020). All aboard for the love parade. https:/www.camh.ca/en/health-info/mentalhealth-and-covid-19/coping-with-covid-19/all-aboard-for-the-love-parade

hooks, bell (1994). Talking Back: Thinking Feminist, Thinking Black (1st ed.). Boston, MA: South End Press.

Hunter (2002). Rethinking epistemology, methodology, and racism: or, is White sociology really dead? Race \& Society, 119-138.

Ingram, R. (2016). Doing Mad Studies: making (non)sense together. Intersectionalities: $A$ Global Journal of Social Work Analysis, Research, Polity, and Practice, 5 (3) 
Jacob, J.D. \& Skinner, E., (2015). Exposing the expert discourse in psychiatry: A critical analysis of an anti-stigma/mental illness awareness campaign. Aporia, 7(1), 5-16.

Janks, H. (1997). Critical discourse analysis as a research tool. Discourse: Studies in the Cultural Politics of Education, 18(3), 329-342. https://doi.org/10.1080/0159630970180302

Joseph, A. J. (2013). A prescription for violence: the legacy of colonization in contemporary forensic mental health and the production of difference. Critical Criminology, 22(2), 273-292. https://doi.org/10.1007/s10612-013-9208-1

Joseph, A.J. (2014). Authorities on the Subject: Deportation and the Confluence of Violence within Forensic Mental Health and Immigration Systems (Doctoral dissertation). Retrieved from Yorkspace. (http://hdl.handle.net/10315/28185).

Joseph, A. J. (2015). The necessity of an attention to Eurocentrism and colonial technologies: an addition to critical mental health literature. Disability \& Society, 30(7), 1021-1041. https://doi.org/10.1080/09687599.2015.1067187

Joseph, A.J. (2019). Constituting lived experience discourses in mental health: the ethics of racialized identification/representation and the erasure of intergenerational colonial violence. Journal of Ethics in Mental Health 10, 1-18.

Khenti, A., Bobbili, S. J., \& Sapag, J. C. (2019). Evaluation of a pilot intervention to reduce mental health and addiction stigma in primary care settings. Journal of Community Health, 44(6), 1204-1213. https://doi.org/10.1007/s10900-019-00706-w

LeBlanc, S., \& Kinsella, E. A. (2016). Toward epistemic justice: a critically reflexive examination of 'sanism' and implications for knowledge generation. Studies in Social Justice, 10(1), 59-78. https://doi.org/10.26522/ssj.v10i1.1324 
Liu, S., Yang, L., Zhang, C., Xiang, Y.-T., Liu, Z., Hu, S., \& Zhang, B. (2020). Online mental health services in China during the COVID-19 outbreak. The Lancet Psychiatry, 7(4), e17-e18. https://doi.org/10.1016/s2215-0366(20)30077-8

Macdonald, S. J., Charnock, A., \& Scutt, J. (2018). Marketing 'madness': conceptualising service user/survivor biographies in a period of deinstitutionalisation (1975-2014). Disability \& Society, 33(6), 849-865. https://doi.org/10.1080/09687599.2018.1463195

Macias (2015). "On the footsteps of Foucault": Doing Foucauldian discourse analysis in social justice research. In S. Strega \& L. Brown (Eds.). Research as resistance: Revisiting critical, Indigenous and anti-oppressive approaches (2nd ed., 221). Toronto: Canadian Scholars' Press.

Martinez, L. R., Xu, S., \& Hebl, M. (2017). Utilizing education and perspective taking to remediate the stigma of taking antidepressants. Community Mental Health Journal, 54(4), 450-459. https://doi.org/10.1007/s10597-017-0174-z

McGinty, E. E., Goldman, H. H., Pescosolido, B., \& Barry, C. L. (2015). Portraying mental illness and drug addiction as treatable health conditions: Effects of a randomized experiment on stigma and discrimination. Social Science \& Medicine, 126, 73-85. https://doi.org/10.1016/j.socscimed.2014.12.010

McKenzie-Mohr, S., \& Lafrance, M. N. (2017). Narrative resistance in social work research and practice: Counter-storying in the pursuit of social justice. Qualitative Social Work: Research and Practice, 16(2), 189-205. https://doi.org/10.1177/1473325016657866 
Menzies, R., LeFrançois, R. \& Reaume, G. (2013). Introducing Mad Studies. In B. A., LeFrançois, R. Menzies, \& G. Reaume's (Eds.), Mad Matters: A critical reader in Canadian Mad Studies. Toronto, Ontario: Canadian Scholar's Press Inc. (pp. 1-21).

Mills, C. W. (2017). Black rights/white wrongs: the critique of racial liberalism (transgressing boundaries: studies in black politics and black communities) (1st ed.). New York, New York: Oxford University Press.

Mills, C. \& LeFrançois, B. (2018). Child as metaphor: colonialism, psy-governance, and epistemicide. World Futures, 74(7-8), 503-524. https://doi.org/10.1080/02604027.2018.1485438

Montgomery, L., Wilson, G., Houston, S., Davidson, G., \& Harper, C. (2018). An evaluation of mental health service provision in Northern Ireland. Health \& Social Care in the Community, 27(1), 105-114. https://doi.org/10.1111/hsc.12627

Moodley, R., Mujtaba, F., Kleiman, S. (2017). Critical race theory and mental health. In B. Cohen (Ed.), Routledge international handbook of critical mental health (1st ed., pp. 7988). London, United Kingdom: Routledge. https://doi.org/10.4324/9781315399584

Morrow, M., Weisser, J. (2012). Towards a social justice framework of mental health recovery. Studies in Social Justice, 6 (1), pp. 27-43.

Nonhoff, M. (2017). Discourse analysis as critique. Palgrave Communications, 3(1), 1-10. https://doi.org/10.1057/palcomms.2017.74

Nguyen, T. (2011) Twitter: a platform for political discourse or social networking. Global Tides, $5(11)$. 
O'Malley, S. (2020). Coping with covid-19: what we can learn from people with mental illness. Centre for Addiction and Mental Health. https://www.camh.ca/en/health-info/mentalhealth-and-covid-19/coping-with-covid-19

Ohlsson, R. (2018). Public discourse on mental health and psychiatry: Representations in Swedish newspapers. Health, 22(3), 298-314.

Oute, J., Huniche, L., Nielsen, C.T., \& Anders, P. (2015). The politics of mental illness and involvement-"a discourse analysis of danish anti-stigma and social inclusion campaigns". Advances in Applied Sociology, 5(11), 273-285.

Pajević I., \& Hasanović, M. (2017) Antipsychiatry as the stigma. Psychiatria Danubina, 29,(5), 890-894.

Pascal-Thompson, M. (2020). A major life change put on hold. https://www.camh.ca/en/healthinfo/mental-health-and-covid-19/coping-with-covid-19/a-major-life-change-put-on-hold

Perlin, M. (2013). Sanism and the law. Virtual Mentor, 15(10), 878-885.

Peeters, R. (2017). Manufacturing responsibility: the governmentality of behavioural power in social policies. Social Policy and Society, 18(1), 51-65. https://doi.org/10.1017/s147474641700046x

Pendenque, S. (2020). Keeping it simple. https:/www.camh.ca/en/health-info/mental-health-andcovid-19/coping-with-covid-19/keeping-it-simple

Peters, M. (2018). How Bell Canada capitalises on the millennial: affective labour, intersectional identity, and mental health. Open Cultural Studies, 1, 395-405. 
Pfefferbaum, B., \& North, C. S. (2020). Mental health and the Covid-19 pandemic. New England Journal of Medicine, 1-3. https://doi.org/10.1056/nejmp2008017

Poole, J. (2020). Doing critical discourse analysis [powerpoint presentation]. Retrieved from https://courses.ryerson.ca/d21/le/content/296758/viewContent/2806904/View

Poole, J. M., Jivraj, T., Arslanian, A., Bellows, K., Chiasson, S., Hakimy, H., Pasini., J., \& Reid, J. (2012). Sanism, 'mental health', and social work education: A review and call to action. Intersectionalities: A global journal of social work analysis, research, polity, and practice, (1), p. 20-36.

Rajkumar, R. P. (2020). COVID-19 and mental health: a review of the existing literature. Asian Journal of Psychiatry, 52, 102066. https://doi.org/10.1016/j.ajp.2020.102066

Reaume, G. (2010). Psychiatric patient built wall tours at the Centre for Addiction and Mental Health (CAMH), Toronto, 2000 - 2010. Left History: An Interdisciplinary Journal of Historical Inquiry and Debate, 15(1), 129-148. https://doi.org/10.25071/1913$\underline{9632.35828}$

Reiss, S. (1972). A critique of Thomas S. Szasz's Myth of Mental Illness. The American Journal of Psychiatry, 128(9), 1081-1085. https://doi.org/10.1176/ajp.128.9.1081

Rimke, H. (2011). The pathological approach to crime: individually based theories. In K. Kramar (Ed.), Criminology: Critical Canadian perspectives (pp. 78-92). Toronto: University of Toronto Press.

Rimke, H. (2016). Introduction-mental and emotional distress as a social justice issue: beyond psychocentrism. Studies in Social Justice, 10 (1), 4-17. 
Rose, D., \& Kalathil, J. (2019). Power, privilege and knowledge: the untenable promise of coproduction in mental "health." Frontiers in Sociology, 4. https://doi.org/10.3389/fsoc.2019.00057

Rovet, J. (2017). Interrogating psychocentrism and the role of a white researcher. Unpublished Major Research Paper. Toronto: Ryerson University, School of Social Work.

Scott, E. (2020). Healthism and veganism. Digital Food Cultures, 68-81. https://doi.org/10.4324/9780429402135-7.

Siolkowsky, I. (2020). Service to others every time. https://www.camh.ca/en/health-info/mentalhealth-and-covid-19/coping-with-covid-19/service-to-others-every-time

Sobande, F. (2020). 'We're all in this together': commodified notions of connection, care and community in brand responses to COVID-19. European Journal of Cultural Studies, 136754942093229. https://doi.org/10.1177/1367549420932294

Strakosch, E. (2015). Analysing Neoliberalism and Settler Colonialism. Neoliberal Indigenous Policy, 33-50. https://doi.org/10.1057/9781137405418_3

Sweeney, A., \& Beresford, P. (2019). Who gets to study whom: survivor research and peer review processes. Disability \& Society, 1-6. https://doi.org/10.1080/09687599.2019.1664062

Tegthsoonian (2009). Depression and mental health in neoliberal times: A critical analysis of policy and discourse, Social Science \& Medicine, 28-35. 
van Dijk, T. A. (1993). Principles of critical discourse analysis. Discourse \& Society, 4(2), 249283. https://doi.org/10.1177/0957926593004002006

van Dijk, T. A. (2005). Discourse analysis as ideology analysis. In. Christina Schaffner and Anita L. Wenden (Eds.), Language \& Peace (pp. 17-36). New York: Routledge. van Dijk T. A. (2006). Ideology and discourse analysis. Journal of Political Ideologies, 11(2), 115-140. https://doi.org/10.1080/13569310600687908

van Dijk, T. A. (2008). Critical discourse analysis and nominalization: problem or pseudoproblem? Discourse \& Society, 19(6), 821-828. https://doi.org/10.1177/0957926508095897

Vido, Jasmine (2019). A critical investigation of Bell Let's Talk (Major Research Paper). Retrieved from https://scholar.uwindsor.ca/major-papers/74.(74).

Vigo, D., Patten, S., Pajer, K., Krausz, M., Taylor, S., Rush, B., ... Yatham, L. N. (2020). Mental health of communities during the COVID-19 pandemic. The Canadian Journal of Psychiatry, 070674372092667. https://doi.org/10.1177/0706743720926676

Voronka, J. (2008). Re/Moving forward?: spacing mad degeneracy at the queen street site. Decolonizing Spaces, 33(1,2), 45-61.

Voronka, J. (2017). Turning mad knowledge into affective labor: The case of the peer support worker. American Quarterly, 69(2), 333-338.

Weedon, C. (1987). Feminist Practice and Poststructuralist Theory. Oxford, United Kingdom: B. Blackwell. 
Whitley, R. (2012). The antipsychiatry movement: Dead, diminishing, or developing? Psychiatric Services, 63(10), 1039-1041. https://doi.org/10.1176/appi.ps.201100484

Wiederhold, B. K. (2020). Social media use during social distancing. Cyberpsychology, Behavior, and Social Networking, 23(5), 275-276. https://doi.org/10.1089/cyber.2020.29181.bkw

Wodak, R. \& Meyer, M. (Eds) (2009) Critical discourse analysis: History, agenda, theory and methodology. In: Methods of Critical Discourse Analysis. Los Angeles U.S.A.: Sage.

Yao, H., Chen, J.-H., \& Xu, Y.-F. (2020). Patients with mental health disorders in the COVID-19 epidemic. The Lancet Psychiatry, 7(4), e21. https://doi.org/10.1016/s2215$\underline{0366(20) 30090-0}$

Zaheer, J. (2020). The best possible outcome from all of this. https://www.camh.ca/en/healthinfo/mental-health-and-covid-19/coping-with-covid-19/the-best-possible-outcome-from$\underline{\text { all-this }}$ 